\title{
Životni suputnici rimskih vojnika na salonitanskim nadgrobnim natpisima iz doba principata
}

\begin{abstract}
$\mathrm{Na} 136$ nadgrobnih natpisa rimskih aktivnih vojnika ili veterana koji se datiraju u doba principata, a potječu iz Salone ili njezina okruženja, spominju se još po jedna ili više osoba. Analiza natpisa pokazala je da ih je najmanje 190, a povezane su s vojnicima i veteranima na različite načine. Najčešće su to njihove žene (coniunx, uxor) s kojima su imali djecu, zatim oslobođenice i oslobođenici koji su imenovani ili navedeni uobičajenom sintagmom (lib. libertaeque), roditelji, krvna braća i tzv. braća po oružju, sestre, hospite, suborci iz postrojbe, prijatelji, robovi, a u pojedinim primjerima punac, šurjak, šurjakinja, prijateljica. Neki su i nasljednici preminulih vojnika i veterana. Rijetki natpisi ne navode u kakvu su odnosu vojnik i druga osoba, ali se to ipak može pretpostaviti. Utvrđuje se tko je koga komemorirao, a analizom imena nastoji se odrediti podrijetlo ovih osoba. Sva tri elementa pomažu da se dokuči društveni status životnih suputnika rimskih vojnika u Saloni.
\end{abstract}

\section{Vojnici i njihovi odnosi s ostalim osobama prema nadgrobnim natpisima}

Najvjerojatnije već od Augustove vladavine vojnici nisu tijekom aktivne službe smjeli sklopiti zakonski pravovaljan brak (conubium). Nije im se branilo da žive u zajednici sa ženama (contubernium, konkubinat) i ne bilježi se da bi zbog toga bili kažnjavani, pa se zaključuje da je država očito tolerirala takve zajednice. Zabrana sklapanja braka najvjerojatnije se nije odnosila na centurione i časnike, a sigurno nije pogađala senatore i vitezove u vojnoj službi. Djeca rođena tijekom očeve službe bila su nezakonita neovisno o tomu je li otac bio legionar ili augzilijar i nisu imala pravo na njegovo imanje osim ako su u oporuci navedena kao nasljednici. Iako su carevi Klaudije i Hadrijan vojnicima dali određene privilegije i riješili pitanja nasljeđivanja, tek im je car Septimije Sever krajem 2. stoljeća dopustio da žive sa svojim ženama i tako omogućio stvaranje zakonitih brakova. ${ }^{1}$ Svi su

\footnotetext{
SCHEIDEL 2007: 417-418; detaljnije v. CAMPBELL 1978: 153-166, a posebno PHANG 2001: 16-52, 86-133, 326-383, također i ALLISON 2011: 165-166. GARNSEY (1970: 45-53) je smatrao da ni nakon 197. godine vojnici nisu imali pravo na sklapanje zakonski priznatog braka. Sklapanje braka podrazumijeva stvaranje obitelji. U rimskome svijetu riječi familia i domus označavale su obitelj odnosno domaćinstvo, a izraz domus bio je općenitiji nego familia; o razlikovanju ovih pojmova i pitanju je li u rimskom svijetu bio zastupljen tip jezgrene ili proširene obitelji v. SALLER 1984: 340-344, SALLER I SHAW 1984: 124-156, KURILIĆ 2008: 39-51.
} 
veterani nakon časnog otpusta iz službe dobili pravo ženidbe (conubium) sa samo jednom partnericom bez obzira na njezin građansko-pravni status. U 1. stoljeću na nadgrobnim natpisima vojnika prilično se rijetko spominju njihove žene. Vojnici su služili daleko od svojih domova gdje nije bilo mnogo žena jednakog društvenog statusa, a u takvom okruženju njihovi su komemoratori gotovo redovito kolege vojnici, posebice oni koje su odredili za nasljednike. Velika mobilnost postrojbi u doba ranog principata također je onemogućavala razvijanje stalnih veza. Međutim, tijekom 2. i posebno 3. stoljeća vojnike sve češće komemoriraju žene i djeca. Ovaj razvoj potaknut je i povećanim provincijskim novačenjima kojima su sačuvane veze s obiteljima i ženama iz lokalne sredine. ${ }^{2}$ Žene vojnika spomenute na natpisima gotovo redovito imaju 20 ili 30 godina, a oko $90 \%$ ih je imalo građansko pravo. ${ }^{3}$ Vojnici za njih rabe izraze uxor, coniunx i marita, znatno su rjeđe nazvane concubina, amica, hospita, rijetko focaria, a katkada i coniunx et liberta. Iako nije jasno kako se pravno gledalo na ove zajednice prije 197. godine - kao na concubinatus ili kao na matrimonia iniusta - moglo bi se govoriti o konkubinatu, ali vojnici nisu marili da se to na natpisu istakne. ${ }^{4}$

U legijama podunavskih provincija tijekom 1 . stoljeća žene se kao komemoratori pojavljuju kod samo $15 \%$ legionara, a istodobno $57 \%$ legionara komemoriraju osobe koje im nisu srodnici, posebice kolege vojnici. U 2. stoljeću udio onih koje komemoriraju žene povećan je na $33 \%$, a u 3 . stoljeću na $45 \%$. U pomoćnim postrojbama slika je više-manje jednaka. Tijekom 1. stoljeća žene su komemoratori u tek $16 \%$ primjera, $53 \%$ komemoracija otpada na kolege iz postrojbe ili na treće osobe. Tijekom 2. i 3. stoljeća žene su komemoratori u 39\% primjera, dok su ostale osobe komemoratori u $29 \%$ primjera. ${ }^{5} \mathrm{U}$ postrojbama koje su novačile pripadnike iz sredine $\mathrm{u}$ kojoj su bile smještene dominira način komemoriranja uvelike sličan onome kod civilnog stanovništva. Potpuno drugačija slika je u postrojbama koje su bile smještene daleko od područja gdje su unovačene. Kod vojnika u Hispaniji, Podunavlju i Africi u više od $70 \%$ svih odnosa dominira jezgrena obitelj, a u Germanijama i Britaniji zastupljenost odnosa s članovima jezgrene obitelji je 35 do $40 \%{ }^{6}$ Kod vojnika u Liburniji veze među članovima jezgrene obitelji čine tek $40 \%$ svih odnosa. Od toga je $12 \%$ odnos frater-fratri (tek za polovicu njih može se sigurno reći da su bili braća samo po oružju). ${ }^{7}$

Vojnik je sebi za iznos dviju godišnjih legionarskih plaća mogao priuštiti vlastitoga roba ${ }^{8}$ a u nekim literarnim izvorima stoji da su robovi pratili vlasnike-

\footnotetext{
2 SCHEIDEL 2007: 419-421, za postotne odnose v. i PHANG 2001: 53-85, 142-164.

PHANG 2001: 190-195, SCHEIDEL 2007: 423-424.

PHANG 2001: 151, 199-201 i dalje.

PHANG 2001: 152-153.

SALLER I SHAW 1984: 139-145.

KURILIĆ 2008: 65-66.

SPEIDEL 1989: 239-245, PHANG 2001: 196.
} 
vojnike na vojnim pohodima. ${ }^{9}$ Vojnici su nakon otpusta primali veću svotu novca (missio nummaria) kojom su mogli kupiti robove, ${ }^{10}$ a mnogi su im oporučno davali slobodu. ${ }^{11}$ Vojnike nerijetko komemoriraju nasljednici koje su mogli odabrati iz različitih skupina. Prema nadgrobnim natpisima vojnika u Germaniji koji završavaju formulom heres ex testamento faciendum curavit, nasljednik je mogao biti roditelj, srodnik, kolega vojnik ili oslobođenik. ${ }^{12} \mathrm{U}$ legijama na Dunavu tijekom 1. stoljeća odnosi vojnika s njihovim oslobođenicama bili razmjerno česti (42\%), a kod pripadnika ratnih mornarica rjeđi (25\%). Oslobođenice se možda spominju na još većem broju natpisa, ali nije naveden njihov oslobođenički status. Može ga se naslutiti prema imenskom obrascu (duo nomina bez filijacije ili libertinacije) ${ }^{13} \mathrm{Nije}$ bilo neobično da se vojnik oženi vlastitom oslobođenicom. Primjerice, pripadnici ravenske i mizenske ratne mornarice to su činili većinom u kasnim dvadesetim godinama, legionari iz logora na obalama Dunava u tridesetim godinama života, a vojnici iz provincija u sjevernoj Africi na to su čekali do stjecanja veteranskog statusa, što jasno govori da su razlike postojale od regije do regije. ${ }^{14}$ Tijekom 1. stoljeća oslobođenice su često (42-50\%) komemoratorice pripadnicima legija u Germaniji, kao i pripadnicima italskih flota (25-59\%), dok u drugim uzorcima taj postotak osjetno varira $(3-35 \%){ }^{15}$

\section{I.1. Osobe s natpisa aktivnih legijskih vojnika}

$$
\text { (T. I., 1. - 40) }
$$

Četrnaest salonitanskih natpisa pripada vojnicima koji su u dalmatinskim legijama služili tijekom 1. st. (T. I., 1-14). Sedma klaudijevska odana i vjerna legija (Legio septima Claudia pia fidelis) je u Dalmaciji boravila od Panonskodalmatinskog ustanka (6-9. godine) do 58-62. godine, ${ }^{16}$ prema čemu se datiraju

9 VISHNIA 2002: 267, SOUTHERN 2006: 224-225.

SOUTHERN 2006: 167, WESCH-KLEIN 2007: 439.

11 PHANG 2001: 243-244. Stjecanje slobode za roba je značilo dobivanje građanskog prava, a s njime i novog imenskog obrasca sastavljenog od patronovog prenomena i gentilicija. Izvorno vlastito ime roba dolazilo je na treće mjesto kao kognomen; v. ROSS TAYLOR 1961: 125, SALWAY 1994: 128. Oslobođenik bez vlastite obitelji postajao je dio familije svojega patrona $\mathrm{s}$ kojim je ojačao stare veze. Time se kao rimski građanin lakše integrirao u društvo; v. TEMIN 2004: 528-529.

CUFF 2010: 114, PHANG 2001: 243-244.

13 PHANG 2001: 193. ROSS TAYLOR 1961: 117, bilj. 13-14 pokazala je na primjerima iz grada Rima da određivanje robovskog ili oslobođeničkog statusa neke osobe na temelju nadgrobnog natpisa nije jednostavan zadatak.

14 SCHEIDEL 2007: 422, v. i PHANG 2001: 194.

15 SCHEIDEL 2007: 425.

16 MARŠIĆ 2010: 74, TONČINIĆ 2011: 12-14, 172. 
natpisi njezinih aktivnih pripadnika. Devet njihovih natpisa sačuvalo je imena drugih osoba. Na prva tri nije uklesan počasni naslov Claudia pia fidelis koji je legija dobila jer je odbila poduprijeti Skribonijanovu pobunu protiv cara Klaudija. Zato se natpisi mogu datirati prije 42 . godine ${ }^{17}$ Nadgrobni žrtvenik oporučno je postavljen konjaniku Marku Ticiju (1) pod nadzorom Lucija Gelija. Većina od desetak potvrda italskog gentilicija Gellius u Dalmaciji ${ }^{18}$ potječe iz Salone. Članovi ove familije vjerojatno su u doba ranog principata pripadali gradskoj aristokraciji: jedan je bio kvatuorvir, neki su imali oslobođenike i zemljoposjede sjeveroistočno od najstarijeg dijela grada. ${ }^{19}$ Možda je Lucije Gelije bio Ticijev suborac iz legije. ${ }^{20}$ Oslobođenica Severa postavila je stelu (2) Gaju Asuriju. ${ }^{21}$ Njezin je kognomen čest u Dalmaciji. U Saloni je potvrđen na 11 natpisa, a među osobama koje ga nose su i dvije oslobođenice. ${ }^{22} \mathrm{Na}$ steli (3) Kvinta Valerija kao komemorator i nasljednik naveden je Lucije Valerije, možda njegov sin ili oslobođenik. Natpis spominje i Kvintovu oslobođenicu Valeriju Kvintu. ${ }^{23}$

Ostali natpisi datiraju se poslije 42. godine. Oslobođenik Lucije Trebonije Sukceso postavio je za njihova života stelu (4) legionaru Luciju Treboniju Valentu, njegovom sinu Luciju Treboniju Konstantu i sestri Treboniji Tertuli. Sukcesov je kognomen čest u zapadnim krajevima Carstva. ${ }^{24}$ Mjesto ukopa na istoj grobnoj parceli osigurao je za sebe i svoje oslobođenike i oslobođenice..$^{25} \mathrm{Zbog}$ oštećenja stele vojnika Gaja Mantika (5) ne može se reći u kakvoj je vezi bio sa spomenutim Gajem Avinijem Postumijem, zasada jedinim nositeljem italskog gentilicija Avinnius u Dalmaciji ${ }^{26}$ i možda Mantikovim suborcem iz postrojbe. ${ }^{27}$ Augustalski sevir Gaj Klodije Feliks, oslobođenik signifera [Gaja Klodija(?) ---] postavio je nadgrobni žrtvenik (6) bivšem gospodaru. Feliks je potvrđen i na vlastitom nadgrobnom natpisu iz Salone koji je za života postavio sebi, kćeri Klodiji Primigeniji i potomcima. ${ }^{28}$ Njegov kognomen tipičan je za pripadnike oslobođeničke

RITTERLING 1925: 1617, BETZ 1938: 36-37, TONČINIĆ 2011: 14, 139-140.

OPEL II: 162, Gellius.

CIL III 1920, CIL III 2343a, v. ALFÖLDY 1969: 87, GABRIČEVIĆ 2015: 217-220.

ALFÖLDY 1969: 87.

MATIJEVIĆ 2015b: 134.

ALFÖLDY 1969: 295.

23 MATIJEVIĆ 2016: 134.

24 ALFÖLDY 1969: 302.

25 MATIJEVIĆ 2016: 134.

26 OPEL I: 96, Avinnius.

27 ALFÖLDY 1969: 64.

28 CIL 3, 2095 (8583): C(aius) Clodius Felix / IIIIIIvir Aug(ustalis) /v(ivus) f(ecit) sibi et / Clodiae Primigeniae $\$$ filiae / posterisque suis; v. i GLAVIČIĆ 2002: 354, kat. br. 211, MATIJEVIĆ 2015b: 134-135. 
populacije u zapadnim krajevima Carstva. ${ }^{29}$ Signiferu Gaju Lukreciju luksuznu su portretnu stelu (7) na grobnoj parceli oporučno podigli brat (frater) čije ime nije navedeno i oslobođenik Krest. Chrestus je ime grčkoga podrijetla i svojstveno pripadnicima oslobođeničke populacije. ${ }^{30}$ Spomenik je postavljen i Primu koji je mogao biti Lukrecijev oslobođenik, rob ${ }^{31}$ ili sin. ${ }^{32}$ Teško je reći je li neimenovani brat bio Lukrecijev suborac iz legije ili stvarni brat, možda upravo veteran Gaj Lukrecije (85) koji je služio u Sedmoj legiji. Mjere grobne parcele identične su na oba natpisa, te su spomenici mogli pripadati istom hortu u vlasništvu njihove obitelji. ${ }^{33}$ Centurion Gaj Vibije Pudent za života je postavio nadgrobni žrtvenik (8) sebi i ženi (uxor) Juliji Poli, Gajevoj kćeri. Njezin gentilicij i kognomen upućuju na italsko podrijetlo. ${ }^{34}$ Centurion Publije Plocije postavio je stelu (9) oslobođeniku Primigeniju koji je preminuo u dvadesetim ili tridesetim godinama života. ${ }^{35}$ Njegov kognomen uobičajen je za oslobođenike u zapadnom dijelu Carstva. ${ }^{36}$

Četiri natpisa pripadaju vojnicima Jedanaeste klaudijevske odane i vjerne legije (Legio undecima Claudia pia fidelis) koja je u provinciju došla kad i Sedma legija, a napustila je nešto kasnije, 68.-69. godine. ${ }^{37}$ Brat (frater) Fabije Fabijan postavio je natpis (10) vojniku Kvintu Fabiju Pakatu. Istovjetni gentilicij upućuje na zaključak da su bili krvna braća. Grad Vijena u Narbonskoj Galiji, koji je Fabijan dao navesti kao domicil brata Pakata, mogao bi biti i njegov zavičaj. Vojnik Marko Blezije Tertul postavio je nadgrobni natpis (11) hospiti (hospita) Papiriji Piralidi. Nije potpuno jasno što izraz hospita točno znači kad se pojavljuje u odnosu s nekim vojnikom, iako je općeprihvaćeno da u takvim okolnostima označava njegovu suložnicu. ${ }^{38}$ Papiriji potječu iz Italije, ${ }^{39}$ a velika većina od 20-ak potvrda njihova gentilicija nađena je u Saloni. Među njima je značajan broj oslobođenika ${ }^{40}$ kojima je prema karakteristikama svoga kognomena mogla pripadati i Piralida ${ }^{41}$ Lucije Varije Leto Pu[---]postavio je

\footnotetext{
$29 \quad$ ALFÖLDY 1969: 202.

30 ALFÖLDY 1969: 176.

31 MATIJEVIĆ 2015b: 135. Kognomen Primus također je uobičajen među oslobođenicima u zapadnom dijelu Carstva, ALFÖLDY 1969: 272.

32 MARŠIĆ 2010: 67.

33 TONČINIĆ 2011: 63.

34 ALFÖLDY 1969: 33, 268, OPEL III: 148, Polla.

35 MATIJEVIĆ 2015b: 134.

36 ALFÖLDY 1969: 271.

37 RITTERLING: 1925, 1693 i d., WILKES 1969: 96-97, FELLMANN 2000: 127 i d.

38 PHANG 2001: 151, 199, KURILIĆ 2006: 133.

39 OPEL III: 123, Papirius.

40 ALFÖLDY 1969: 107.

41 ALFÖLDY 1969: 277.
} 
nadgrobni žrtvenik (12) centurionu Luciju Variju [---] i Beniji Sabini. Oštećenost natpisa dopušta različite pretpostavke o karakteru njihovih međusobnih odnosa. Istovjetni centurionovi i Letovi prenomen i gentilicij sugeriraju da su otac i sin ili gospodar i oslobođenik. Slova $P V[---]$ iza kognomena mogla bi biti početak Letova signuma ili riječi puer koja na dalmatinskim natpisima nije česta, ali je ipak potvrđena s nekoliko primjera ${ }^{42}$ Prema tom tumačenju Benija Sabina je najvjerojatnije centurionova žena. Pripadala je istaknutoj salonitanskoj familiji koja je dala nekoliko pojedinaca na važnijim vojnim i upravnim funkcijama u Dalmaciji i Saloni. ${ }^{43}$ Druga je mogućnost da su slova $P V[---]$ početak sigle za formulu $p$ (ater) $v$ (ivus) [filio suo et sibi]. Prema tom tumačenju Lucije Varije Leto i Benija Sabina bili bi centurionovi otac i majka. ${ }^{44}$ Čini se da je to ipak manje vjerojatno jer pretpostavlja da su roditelji došli s njime u Dalmaciju nakon što je u rodnoj Augusti Pretoriji unovačen u legiju. Stoga se ipak čini da je Benija Sabina centurionova žena, a Leto njihov sin, ili čak oslobođenik. Takve su veze potvrđene na natpisu (13) legijskog centuriona Julija Paterna. Na natpisima iz razdoblja ranog principata roditelji se rijetko navode kao komemoratori sinova vojnika. U Saloni to pokazuju samo natpisi (16) konzularskog beneficijarija Proklina i viteza Pakuvijana. ${ }^{45}$ Centurionu Marku Juliju Paternu nadgrobni natpis (13) oporučno su postavili žena Julija Maksima, Titova kći, i oslobođenik Marko Julije Dokim, ujedno i nasljednik. Paterno im je za podizanje spomenika ostavio 10.000 sestercija što jasno govori da je želio da bude bogato opremljen. ${ }^{46} \mathrm{Julija}$ Maksima je italskog podrijetla, ${ }^{47}$ oslobođenik nosi kognomen grčkog podrijetla tipičan za oslobođenike. ${ }^{48}$

Jedan nadgrobni natpis pripada vojniku Četvrte flavijevske sretne legije (Legio quarta Flavia felix) koja je u provinciji boravila između 70. godine i sredine 80 -ih godina. ${ }^{49}$ Vojniku Luciju Mariju Fortunatu (14) postavio ga je brat (frater) Marko Eupunije Viktor. Različiti gentiliciji mogu značiti da su bili krvna braća po majci ili suborci iz iste legije odnosno „braća po oružju. “50 Vojnici su na epitafima

\footnotetext{
42 CIL III 9165 i ILIug 2206 (Salona), CIL III 14321.26 (Burnum), CIL III 13256 (Aserija), ILIug 665 (Brela), ILS 8516 (Baška voda), ILIug 1612 (Zenica).

43 ALFÖLDY 1969: 66-67. O vitezovima, gradskim dužnosnicima u Ekvu i Saloni, te o pripadnicima namjesnikova oficija iz ove familije detaljnije v. MATIJEVIĆ 2017a: 200.

44 MATIJEVIĆ 2017a: 200.

45 CIL III 2049.

46 MATIJEVIĆ 2016: 136-137.

47 ALFÖLDY 1969: 31-33.

48 ALFÖLDY 1969: 190.

49 RITTERLING 1925: 1541-1542, BETZ 1938: 47, WILKES 1969: 97, bilj. 2; LE BOHEC I WOLFF 2000: 239, v. i JONES 1974: 49.

50 PHANG 2001: 151, 162, LENDON 2006: 271, v. i WILKES 1969: 104, bilj. 1.
} 
gotovo redovito ovim izrazom iskazivali povezanost. ${ }^{51}$ Eupunijevo podrijetlo ne može se odrediti jer njegov gentilicij nije potvrđen drugdje u Carstvu. ${ }^{52}$ Eupunije Viktor je natpis postavio i supruzi (coniunx) Ekvitini Terciji koja je zasad jedini poznati nositelj gentilicija Aequitinus u europskom dijelu Carstva i vjerojatno je italskog podrijetla. $^{53}$

Tri su natpisa postavljena legijskim vojnicima koji su služili kasnije tijekom ranog principata (T. I., 15-17). Centurionu Titu Flaviju Pomponijanu iz Druge trajanovske silne legije (Legio secunda Traiana fortis) natpis (15) su tijekom hadrijanskog doba postavili nasljednici, možda centurioni iz legije, čija imena nisu navedena. ${ }^{54}$ Majka Epidija Prokula postavila je tijekom tridesetih ili četrdesetih godina 2. stoljeća nadgrobni žrtvenik sinu, konzularskom beneficijariju Luciju Graniju Proklinu (16) iz Četrnaeste dvojne legije (Legio quarta decima gemina). U njegovoj je familiji bilo oslobođenika i oslobođenica, ali njihova imena nisu navedena. Možda je Proklin u južnom dijelu salonitanskog agera uz grobnu parcelu posjedovao i imanje gdje su mogli raditi neki njegovi oslobođenici. ${ }^{55}$ Majka nosi italski gentilicij Epidius ${ }^{56}$ čiji su nositelji potvrđeni u Jaderu i Dokleji. ${ }^{57}$ Natpis iz Britanije izričito spominje Epidija, vojnika s civitetom rodom iz Ekva. ${ }^{58}$ Epidija sigurno nije došla iz druge provincije kako bi sinu ovdje postavila luksuzan nadgrobni spomenik, što znači da je ovo bio njezin rodni kraj ${ }^{59} \mathrm{i}$ da je bila prilično imućna. Dvije osobe postavile su tijekom prve polovice 2. stoljeća stelu (17) spekulatoru Titu Ti[---]. Zbog oštećenosti spomenika ne može se odrediti u kakvu su odnosu bile s njime. Od imena prve ostalo je sačuvano T[---] EVPHRO[---], a od imena druge $T$ T[---]. Kognomen prve osobe mogao bi biti Euphrosynus i upućivao bi na osobu oslobođeničkog statusa, ${ }^{60}$ posebno zato što natpis jasno govori da je ovaj spekulator imao oslobođenike i oslobođenice. O drugoj se osobi može reći samo da je bila muškarac s građanskim pravom. ${ }^{61}$

51 COSME I FAURE 2004: 346. Kod većine civilnih populacija komemoracije frater - fratri iznose $4-5 \%$ svih odnosa, dok je u vojnim postrojbama, primjerice u carskoj konjaničkoj straži u Rimu ili u nekim jedinicama u Germaniji, ovakav odnos zastupljen u gotovo polovici primjera, SALLER I SHAW 1984: 141.

52 ALFÖLDY 1696: 84, OPEL II: 127, Eupunius.

53 ALFÖLDY 1696: 55, OPEL I: 31, Aequitinus.

54 Za dataciju v. DEMICHELI 2015: 64.

55 CAMBI I RAPANIĆ 1979: 98-104, MATIJEVIĆ 2016: 139.

56 OPEL II: 120, Epidius.

57 ALFÖLDY 1969: 83.

$58 \quad E D H$ HD015986.

59 Roditelji vojnika najčešće postavljaju djeci nadgrobne spomenike u provinciji u gdje žive, v. DEMICHELI 2015: 66.

60 ALFÖLDY 1969: 197.

${ }_{61}$ Detaljnije o dataciji spomenika i imenima v. MATIJEVIĆ 2015b: 138. 
Deset natpisa (T. I., 18-28) spominje pripadnike šest različitih legija (Prve italske, Prve pomoćnice, Desete i Četrnaeste dvojne, Jedanaeste , Treće kirenaičke) koji su u doba kasnoga principata obavljali visokorangirane službe u namjesnikovu oficiju. ${ }^{62}$ Vizelija Julija i majka Ebucija Januarija komemorirale su na steli (18) komentarijenza Tiberija Klaudija Januarija. Gentilicij Visellius latinskog je podrijetla i poznat u zapadnim provincijama, ${ }^{63}$ a gentilicij Aebutius je sjevernoitalskog podrijetla i u doba kasnog principatu potvrđen je isključivo u Saloni. ${ }^{64}$ Poncije Viator postavio je stelu (19) spekulatoru čije ime nije sačuvano i kojega je nazvao bratom (frater). Gentilicij Pontius potječe iz Italije odakle je najviše njegovih potvrda, ${ }^{65}$ kognomen Viator posvuda je rasprostranjen. ${ }^{66}$ Kći Valerija Sabina komemorirala (20) je spekulatora Lucija Valerija Augustala. Njezin je kognomen posebno čest u Italiji, na zapadu, u Noriku i Panoniji. ${ }^{67}$ Šest je natpisa postavljeno beneficijarijima. Supruga (coniux) i brat postavili su stelu Gaju Juliju Saturninu (21). Gentilicij supruge Domicije Belike, Markove kćeri, posvuda je rasprostranjen, a u Dalmaciji ga nose Italici i Orijentalci. ${ }^{68}$ Kognomen zasada nema drugih potvrda u provinciji ${ }^{69}$ za razliku od drugih dijelova Carstva, posebno Norika. ${ }^{70}$ Drugi komemorator, Saturninov brat (frater) zove se Gaj Julije Puzinion. Osoba istoga imena spominje se na natpisu iz Akvinka kao pripadnik Druge legije pomoćnice (Legio secunda adiutrix). ${ }^{71}$ Kognomen Pusinnio tipičan je za keltske oblasti, ${ }^{72}$ a najviše potvrda potječe iz Panonije. ${ }^{73}$ Elije Marcijan postavio je nadgrobni natpis (22) djevojčici Faniji Maksimi koja je živjela dvije godine i devet mjeseci. Gentilicij Fanius je italskog podrijetla. Zasada je u Saloni tijekom kasnoga principata potvrđen još samo jedanput. ${ }^{74}$ Ulpiju Justinu (23) stelu je postavila majka čije ime nije navedeno, Luciju Vetiju Probu stelu (24) su podigla djeca Lucije Vetije Grato i Vetija Januarija. Elija Tetida (ili Tetija) postavila je nadgrobni natpis (25) Publiju Eliju Lupu, kćerima Vibiji Forti i Eliji

\footnotetext{
MATIJEVIĆ 2015a: 132-148.

63 ALFÖLDY 1969: 338, OPEL IV: 175, Viselius.

64 ALFÖLDY 1969: 54; OPEL I: 24-25, Aebutius.

65 ALFÖLDY 1969: 112, OPEL III: 153, Pontius.

66 ALFÖLDY 1969: 326, OPEL IV: 164-165, Viator.

67 ALFÖLDY 1969: 285.

68 ALFÖLDY 1969: 82, OPEL II: 105-106, Domitius.

69 ALFÖLDY 1969: 164.

70 OPEL I: 117, Bellicus.

71 CBFIR 479. CIL III 3489: N\{y=I\}mphis / sacrum / Iul(ius) Pusinio / imm(unis) leg(ionis) II $\beta$ [a]d(iutricis) $\{p=r\}$ (iae) f(idelis) v(otum) l(ibens) m(erito).

72 ALFÖLDY 1969: 277.

73 OPEL III: 173, Pusinnio.

74 U Dalmaciji je poznat i kao Fannius, ALFÖLDY 1969: 85, OPEL II: 134, Fanius, Fannius.
} 
Ursili čije je ime kasnije dodano, što bi moglo značiti da je kasnije i umrla, u dobi od 25 godina. Njezin je kognomen italskog podrijetla i u Dalmaciji poznat na još tri natpisa, potvrđen rijetko samo u Italiji ${ }^{75}$ Svi dalmatinski primjeri rijetkoga grčkog kognomena Tethis potječu iz Salone. ${ }^{76}$ Ursila i Tetida (ili Tetija) nose gentilicij Aelius. Ursila ga je dobila od oca, a Tetida (ili Tetija) pripadala familiji koja je također civitet dobila od cara Hadrijana ili Antonina Pija. ${ }^{77}$ Gentilicij Vibije Forte italskog je podrijetla, od 23 dalmatinske epigrafske potvrde iz doba kasnoga principata čak 17 ih je iz Salone i okolice. ${ }^{78}$ Kognomen Fortis posvuda je rasprostranjen. ${ }^{79}$ Emilija Afrodita postavila je nadgrobni žrtvenik (26) beneficijariju i patronu Kvintu Emiliju Rufu. Nema sumnje da je bila njegova oslobođenica jer ga je nazvala patronom i nosi njegov gentilicij. ${ }^{80} \mathrm{Njezin} \mathrm{je} \mathrm{kognomen}$ orijentalnog podrijetla i uobičajen za oslobođenice. ${ }^{81}$ Sestra Restuta i prijatelj [---] annus postavili su natpis (27) beneficijariju ili kornikulariju [---]koniju [---]inu. Restutin je kognomen osobito rasprostranjen u Italiji i keltskim oblastima, od 15 dalmatinskih epigrafskih potvrda samo jedna nije iz Salone. ${ }^{82}$ Nije poznato kako je glasio kognomen drugoga komemoratora ([---]annus) ${ }^{83}$ Oslobođenik Firmin postavio je stelu (28) centurionu frumentariju Titu Varoniju Maronu. Firminovo je ime posvuda rasprostranjeno, posebno u Italiji, a gotovo sve njegove epigrafske potvrde iz Dalmacije pripadaju vremenu kasnog principata. ${ }^{84}$ Služba frumentarija zahtijevala je od vojnika veliku mobilnost pa se smije pretpostaviti da je Firmin pratio Varona na zadatcima koje je obavljao diljem Carstva. Dobra analogija je reljef nadgrobnog spomenika (ILS 2378) iz Viminacija na kojemu je prikazan sluga kako nosi koplje svoga gospodara spekulatora, namještenika provincijskog oficija u Meziji. ${ }^{85}$ Rimski epitafi frumentarija rijetko spominju žene i djecu, a brigu oko pokopa preuzimali su nasljednici, oslobođenici i posebno kolege iz numera koji su često bili iz iste legije. Ovo ukazuje da su se odnosi prijateljstva i solidarnosti razvili u okviru provincije, legije, oficija i nastavili u Rimu gdje su ovi vojnici bili izdvojeni. Izvršavanje zadaća često u najudaljenijiim dijelovima

\footnotetext{
75 ALFÖLDY 1969: 317, OPEL IV: 201, Ursilla.

76 ALFÖLDY 1969: 310, v. i OPEL IV: 120, Thetis.

77 ALFÖLDY 1969: 43-44.

78 ALFÖLDY 1969: 136-137.

79 ALFÖLDY 1969: 206, OPEL II: 150, Fortis.

80 MATIJEVIĆ 2016: 139.

81 ALFÖLDY 1969: 174-175.

82 ALFÖLDY 1969: 282, OPEL IV: 28, Restutus.

83 U literaturi prevladava pretpostavka da je riječ o kognomenu Tyrannus koji je grčkoga podrijetla, vrlo je rijedak i u Dalmaciji nije potvrđen, v. ALFÖLDY 1969: 316, OPEL IV: 136, Tyrannus. ALFÖLDY 1969: 204; OPEL II: 142, Firminus.

RANKOV 1990: 182.
} 
Carstva i kratkotrajnost boravka frumentarija na misijama mogu objasniti rijetku potvrđenost žena i djece koji nisu pratili muževe i očeve. ${ }^{86}$

Jedanaest natpisa može se datirati u 3. stoljeće ili općenitije u doba kasnog principata (T. I., 29-40). U seversko doba, a vjerojatno i kasnije, u Saloni je boravila veksilacija Prve italske legije (Legio prima Italica) što potvrđuje šest natpisa njezinih pripadnika. ${ }^{87}$ Aurelije Sabazijan postavio je stelu (29) Aureliju Mukatri, suborcu iz postrojbe o čemu svjedoči sintagma miles legionis supra scriptae. Sabazijanov je kognomen izveden iz imena tračko-frigijskoga boga Sabazija, što ukazuje da je, poput Mukatre, podrijetlom iz tog dijela Carstva. ${ }^{88}$ Vojniku nepoznatog imena stelu (30) je podigao suborac Aurelije Marcijan. Marcijanov kognomen posvuda je rasprostranjen, a u Dalmaciji je zastupljen gotovo isključivo tijekom kasnog principata. ${ }^{89}$ Služili su u istoj legiji što dokazuje uporaba sintagme kao na prethodnom natpisu, ali i imenice contubernalis koja se gotovo redovito pojavljuje uz ime vojnika iz iste postrojbe. ${ }^{90}$ Sin Aurelije Kvincijan postavio je stelu (31) vojniku Aureliju Poncijanu. Kvincijanov je kognomen posvuda evidentiran, uobičajen u Dalmaciji gdje sve potvrde pripadaju vremenu kasnog principata. ${ }^{91}$ Vojniku Aureliju Marcijalu, njegovoj supruzi Eliji i sinu Marcijalu postavio je nadgrobni natpis (32) brat i njihov nasljednik Disdozi. Žena je imenovana samo gentilicijem prema čemu bi se moglo pretpostaviti da je pripadala familiji koja je civitet dobila u doba Hadrijana ili Antonina Pija, sin nosi očev kognomen Martialis koji je posvuda rasprostranjen i potvrđen nekoliko puta u Dalmaciji. ${ }^{92}$ Komemorirao ih je Marcijalov brat Disdoz čije je ime tračkoga podrijetla i izrazito rijetko. ${ }^{93}$ Vojnik Aurelije Januarije i Kvirila postavili su nadgrobni natpis (33) četrnaestogodišnjem sinu Eliju Vitalu. Ovo je zasad jedina dalmatinska potvrda kognomena Quirilla. ${ }^{94}$ Sinov kognomen Vitalis posvuda je izrazito rasprostranjen, posebno u keltskim i tračkim predjelima, ali i u Dalmaciji. ${ }^{95}$ Nasljednik Julije postavio je nadgrobni natpis (34) vojniku čije ime nije sačuvano. Julijev gentilicij pokazuje da je imao građansko pravo. Veliki broj osoba iz ove skupine natpisa nosi gentilicij Aurelius što sugerira da su civitet dobili Karakalinom Constitutio Antoniniana 212. godine. ${ }^{96}$

\footnotetext{
86 COSME I FAURE 2004: 350-351.

87

88 TUDOR 1971: 88. OPEL IV: 39 navodi samo ovu potvrdu toga kognomena. 
Tijekom kasnoga principata u Saloni je bila veksilacija Četrnaeste dvojne legije. ${ }^{97}$ Atrekciju Cezijanu stelu (35) su postavile supruga Aurelija Festa i majka Atrekcija koja je na natpisu nazvana majčicom (mamula). Isti gentilicij majke i sina može se objasniti ako je ona bila ropkinja, a zatim oslobođenica Atrekcijeva oca. ${ }^{98} \mathrm{U}$ Dalmaciji je gentilicij Atrectius potvrđen samo u ovom primjeru. Upućuje na podrijetlo iz Norika, Galije Belgike ili Germanije odakle potječu sve ostale potvrde ${ }^{99}$ Kognomen supruge Feste rasprostranjen je posvuda, a potvrđen je i u keltskim područjima. ${ }^{100}$ Iako je gentilicij Atrekcije vjerojatno stran, majka kao komemorator upućuje na lokalnu pripadnost familije. ${ }^{101}$ Nasljednik i suborac iz jedinice (miles legionis eiusdem) Ulpije Kalija postavio je stelu (36) vojniku Aviciju Augurinu. Zasad nema drugih potvrda njegova kognomena u Dalmaciji, ${ }^{102}$ a izrazito je rijedak i u ostatku Carstva. ${ }^{103}$

Centurion Pete makedonske legije (Legio quinta Macedonica) Aurelije Vital postavio je početkom 3. stoljeća sarkofag (37) ženi Celiji Kalpurniji koja je preminula u 26. godini života. Na istom mjestu koje je Aureliju Vitalu ustupila prijateljica Julija Vetija pokopana je i Kalpurnijina sestra Elija Pomponija. ${ }^{104}$ Sve tri ženske osobe imaju građansko pravo. Gentilicij centurionove žene posvuda je rasprostranjen i čest u Dalmaciji. ${ }^{105}$ Kognomen Calpurnius daleko je više puta potvrđen kao gentilicij ${ }^{106}$ što vrijedi i za kognomene pokojničine sestre (Pomponius) ${ }^{107}$ i njihove prijateljice (Vettius) ${ }^{108}$ Beneficijarij Flavije Valent postavio je u 3. stoljeću sarkofag (38) supruzi Kvinciji C[---], kćeri pokojnog primipila Kvincija Germana, koja je preminula s 30 godina. ${ }^{109}$ Oslovljena je kao femina stolata što označava njezin

97 MATIJEVIĆ 2015a: 52-53.

98 DEMICHELI 2015: 69.

99 ALFÖLDY 1969: 63, OPEL I: 87, Atrectius.

100 ALFÖLDY 1969: 203.

101 DEMICHELI 2015: 69. Na isti način bi se eventualno moglo gledati i na komentarijenza Januarija (18) i beneficijarija Justina (23) koje su komemorirale njihove majke. Zaista, tijela preminulih vojnika u pojedinim su prigodama vraćena u rodni kraj ako su njihove obitelji identificirale njihove ostatke i osigurale transport. Nisu svi mogli platiti repatrijaciju, a pitanje je tko je uopće od članova obitelji bio kod kuće kako bi sve organizirao nakon što je vojnik već bio dugo odsutan. Nemoguće je reći koliko je vojnika nakon smrti vraćeno svojim obiteljima, ali nema sumnje da je riječ o izraziro malom broju jer ih je većina gotovo sigurno bila pokopana na nekropolama u blizini mjesta svoje vojne službe, CARROLL 2009: 824-825.

102 ALFÖLDY 1969: 168.

103 OPEL II: 23, Callia.

104 Za dataciju v. CAMBI 2010: 37, 39, 66-67.

105 ALFÖLDY 1969: 76-77, OPEL II: 68, Coelius.

106 ALFÖLDY 1969: 169.

107 ALFÖLDY 1969: 269.

108 ALFÖLDY 1969: 326.

109 Za dataciju prema izrazu femina stolata v. HOLTHEIDE: 1980, 127-134. 
visoki društveni status i moralne vrline. ${ }^{110}$ Gentilicij Quintius posebno je čest na zapadu i u sjevernoj Italiji ${ }^{111}$ što se može reći i za kognomen Germanus. ${ }^{112}$ Legionaru Luciju Bebiju[---] stelu (39) je postavila Cezidija [---] čiji gentilicij ukazuje na italsko podrijetlo. ${ }^{113}$ Možda je bio Cezidijin otac jer je tako oslovljen (patri). Natpis je sačuvan samo djelomično, pa je na njemu moglo biti uklesano ime jednoga djeteta ili više njih. To bi moglo značiti da je Cezidija bila Bebijeva žena. Legijski centurion Tit Ticizen Valentin postavio je između 1. i 3. stoljeća natpis (40) ocu Titu Ticizenu Konviktorijanu, dekurionu i svećeniku carskoga kulta. ${ }^{114}$ Gentilicij Titisenus italskog je podrijetla, ${ }^{115}$ dok je kognomen Convictorianus u europskim dijelovima Carstva poznat samo preko ovoga primjera. ${ }^{116}$

\section{I.2. Osobe s natpisa aktivnih pripadnika pomoćnih postrojbi i mornarice}

$$
\text { (T. I., 41-69) }
$$

Iz prve polovice 1. stoljeća potječu dva nadgrobna natpisa časnika koji su služili u alama. ${ }^{117}$ Natpis na steli (41) dekuriona Partske ale (Ala Parthorum) Tiberija Julija Maksima spominje Seksta Celija. Njegov je gentilicij čest svugdje, pa i na Istoku, ${ }^{118}$ što je u ovom primjeru znakovito jer je postrojba ondje osnovana. Celije ima civitet pa se smije pretpostaviti da je poput Maksima obavljao neku zapovjednu funkciju u jedinici i da je najvjerojatnije komemorirao Maksima. Osoba od čijeg je imena ostalo sačuvano Ca[---] postavila je natpis (42) duplikariju Panonske ale (Ala Pannoniorum) Kluciju Klutamovu. Možda je podrijetlom bila iz sjeverozapadne Hispanije odakle i Klucije (Susarrus, domo Curunniace) i gdje se novačilo za ovu postrojbu. Dobra analogija je natpis iz Gyalóke u Gornoj Panoniji iz 1. stoljeća kada su konjaniku iz ove postrojbe spomenik podigla dvojica njegovih kolega podrijetlom iz sjeverozapadne Hispanije. ${ }^{119}$ Prema tome se smije pretpostaviti da je $\mathrm{Ca}[---]$ početak imena Klucijeva suborca iz jedinice. ${ }^{120}$

110 HOLTHEIDE 1980: 127-131, OLSON 2008: 50, 113.

111 ALFÖLDY 1969: 114, OPEL IV: 19-20, Quintius.

112 ALFÖLDY 1969: 211, OPEL II: 166, Germanus.

113 ALFÖLDY 1969: 69.

114 Za dataciju Bebijevog i Ticizenovog natpisa v. MATIJEVIĆ 2015a: 54-55.

115 ALFÖLDY 1969: 127.

116 ALFÖLDY 1969: 180, OPEL II: 74, Convictorianus. Prema EDCS riječ je o jedinoj potvrdi u Carstvu.

117 MATIJEVIĆ 2015a: 56-57.

118 ALFÖLDY 1969: 76-77.

119 CIL III 4227, v. SPAUL 1995: 71-73, PITILLAS SALAÑER 2006: 31, br. 3, 5, 10.

120 Možda je glasilo Caturo, poput patronimika vojnika (Meduttus Caturonis f.) iz Prve brakaraugustanske kohorte iz Bigesta (ILIug 1928) koji je podrijetlom također bio iz tog dijela Hispanije, v. PITILLAS SALAÑER 2006: 31, br. 8. 
Vojniku Epikadu, sin Piramovu, iz Treće kohorte alpinaca (Cohors tertia Alpinorum), stelu (43) je postavio prijatelj i konjanik Plarent, sin Anejev tijekom flavijevsko-trajanskog doba. Vjerojatno je u toj kohorti služio s Epikadom ${ }^{121}$ i vuče podrijetlo iz jugoistočnih krajeva Dalmacije. ${ }^{122}$ Dekurion Prve kohorte Belgâ (Cohors prima Belgarum) Gaj Valerije Prokul postavio je stelu (44) sebi, ženi (uxor) Apuleji Sabini te oslobođenicima i oslobođenicama vjerojatno između 120. i 130. godine. ${ }^{123}$ Apuleja Sabina je italskog podrijetla. ${ }^{124}$ Od svih vojnika iz peregrinskih pomoćnih odreda u Saloni zasada je jedino je Prokul imao veći broj oslobođenika i oslobođenica. To je morao biti odraz njegova dobrog imovinskog statusa koji je proizašao iz veće plaće zbog časničkih službi. ${ }^{125}$ Centurion iste postrojbe, Kvint Servilije Stacijan, postavio je nadgrobni žrtvenik (45) supruzi (coniux) Kalpurniji Nimfi sredinom 2. stoljeća. ${ }^{126}$ Ovo je u Dalmaciji zasada jedina potvrda njezina kognomena koji bi mogao upućivati na oslobođeničko podrijetlo. ${ }^{127}$ Gentilicij Calpurnius posebno je čest na zapadu, a u Dalmaciji na području Liburnije. ${ }^{128}$ Jednako se datira i nadgrobni žrtvenik (46) koji je hospita Julija Fruktula postavila pomoćniku konzularskih kornikularijâ Titu Staciliju Maksimu i sebi. ${ }^{129}$ Njezin je kognomen u provinciji poznat samo na još jednom natpisu u Saloni i izrazito je rijedak. ${ }^{130}$

Iz vremena kasnoga principata potječe 21 natpis aktivnih augzilijara. ${ }^{131}$ (T. I., 47.-69). Vojnik Licinije Kapiton(?) iz Prve kohorte Belgâ postavio je stelu (47) sebi i nekom Fortunatu [---] čiji je kognomen u Dalmaciji karakterističan za oslobođeničku populaciju. ${ }^{132}$ Dva nadgrobna natpisa pripadala su vojnicima Treće kohorte alpinaca. Viktoriju Nepotu stelu (48) je podigla osoba čije je ime oštećeno. Uklesano je u 6. ([---]CVND[---]) i 7. retku (TFRTI). Slijedi dativ imenice contubernalis kojom je komemorator oslovio preminuloga vojnika. Čini se da se mogu iznijeti dvije pretpostavke o obliku komemoratorovog imena.

\footnotetext{
121 Detaljno o ovome natpisu i pitanju datacije v. MATIJEVIĆ 2016: 198-200.

122 ALFÖLDY 1969: 150, 267, v. i ALFÖLDY 1987: 281, bilj. 17, BOJANOVSKI 1988: 95. Alföldyjevu tvrdnju o Plarentovu dalmatinskom podrijetlu prihvaća i SPEIDEL (1978: 88). DEMICHELI (2015: 72) kaže da je Plarent možda bio Salonitanac.

123 Za dataciju v. MATIJEVIĆ 2011: 191.

124 ALFÖLDY 1969: 60, 285, OPEL I: 67-68, Appuleius.

125 MATIJEVIĆ 2015b: 137.

126 Za dataciju v. CAMBI 2005: 101, 102.

127 ALFÖLDY 1969: 254.

128 ALFÖLDY 1969: 70-71, OPEL II: 25-26, Calpurnius.

129 Za dataciju v. CAMBI 1960 (1967): 59, 67-68.

130 ALFÖLDY 1969: 208, OPEL II: 153, Fructula.

131 Za njihovu dataciju v. MATIJEVIĆ 2015a: 63, 70.

132 ALFÖLDY 1969: 206.
} 
U 6. retku bi mogao biti ostatak gentilicija, ali u Dalmaciji nema niti jednoga koji sadrži ovakav redoslijed slova. Mogao bi to biti gentilicij Secundius koji je potvrđen na natpisima iz zapadnog dijela Carstva. ${ }^{133}$ Natpisno polje stele može se jasno definirati. U donjem desnom kutu sačuvan je početak okomite profilacijske letvice koji pokazuje da je bilo dovoljno mjesta da se uklešu preostala slova toga gentilicija. Tada je u sljedećem retku bio uklesan kognomen Tertius. ${ }^{134}$ Prema tome se smije zaključiti da je komemorator Sekundije Tercije bio contubernalis preminuloga Nepota. On je mogao biti njegov kolega iz jedinice kao što pokazuju primjeri stela vojnika Prve italske legije $(29,30)$, a mogao je biti i civil, sukladno jednom nadgrobnom natpisu iz Mezije na kojemu je muška osoba upravo ovom imenicom oslovila drugu mušku osobu. ${ }^{135}$ Sadržaj natpisa ne omogućava određivanje karaktera njihove povezanosti. Prema trećoj mogućnosti radi se o ženskoj osobi što se ne kosi s upotrebom imenice contubernalis jer neki natpisi pokazuju da je upotrebljavana kada je žena komemorator muškarcu ili obrnuto ${ }^{136}$ odnosno za osobe robovske i oslobođeničke populacije. ${ }^{137}$ Treba spomenuti i mogućnost po kojoj je u 6. retku bio ostatak kognomena neke Sekundine, kćeri nekog Tercija (Secundina Terti (filia)). ${ }^{138}$ Veksilariju Gaju Bebidiju Marcelu stelu (49) je postavila Ana. Nazvala ga je gojencem (alumnus) prema čemu bi se moglo reći da je bila njegova posvojiteljica. ${ }^{139}$ Nosi ime ilirskog ili hebrejskog podrijetla. ${ }^{140}$

Deset natpisa koji se datiraju u doba kasnog principata do sredine 3. stoljeća ${ }^{141}$ pripadalo je vojnicima iz Osme dobrovoljačke kohorte (Cohors octava voluntariorum) (T. I., 50-59). Konzularski frulaš Publije Benije Priscijan postavio je stelu (50) hospiti Valeriji Maksimi. Valerius je najrasprostranjeniji necarski gentilicij koji je u Dalmaciji tijekom kasnoga principata epigrafski najzastupljeniji u Saloni. ${ }^{142}$ Maksima nosi jedan od najčešćih kognomena u rimskome svijetu. ${ }^{143}$ Gospodaru (dominus) i vojniku Gaju Publiju(?) Veru stelu (51) je postavio Helije.

\footnotetext{
133 OPEL IV: 59, Secundius.

134 ALFÖLDY 1969: 307-308.

135 EDH HD057038 (Nova Varoš): D(is) M(anibus) / Celtemio / v(ixit) a(nnos) LXX Titus / Plati $v$ (ivus) t(itulum) v(ivo) i(psi) p(osuit) \& s(ibi) e(t) cont(ubernali).

136 CIL III 3150 (Kreksa), CIL III 1760 (Epidaurum), CIL III 12712, CIL III 14600 (Dokleja), CIL III 2336, CIL III 2390, CIL III 9488, ILIug 2217 (Salona).

137 LENDON 2006: 270; posebno v. TREGGIARI 1981: 42-69.

138 ALFÖLDY 1969: 290. STICOTTI (1893: 148) predlaže kognomen Iucunda.

139 RAWSON 2005: 253.

140 ALFÖLDY 1969: 150, 348, 360, 363, OPEL I: 55, Anna.

141 MATIJEVIĆ 2015a: 72-73, 152-153.

142 ALFÖLDY 1969: 131.

143 ALFÖLDY 1969: 242-245, OPEL III: 70-71, Maximus.
} 
Njegov je kognomen grčkoga podrijetla, u Dalmaciji potvrđen isključivo u Saloni kod robovske i oslobođeničke populacije, ${ }^{144}$ što zajedno s načinom oslovljavanja sugerira da je Helije bio rob. Ako je ovo ispravno, onda je Gaj Publije(?) Ver jedini aktivni vojnik iz Dalmacije za kojega je dosad epigrafski potvrđeno da je imao vlastitog roba. ${ }^{145}$ Majka Kalpurnija podigla je stelu (52) vojniku Luciju Sorniju C[---]. Sačuvan je prvi slog Pro[---] njezina kognomena. U obzir može doći najmanje 20-ak kognomena od kojih je u Saloni daleko najbrojniji Procula. ${ }^{146}$ Upravo taj kognomen nosi Maksimija Prokula, majka koja je komemorirala trubača Ulpija Nepota (53). Njezin je gentilicij potvrđen na zapadu, posebno u Narbonskoj Galiji. ${ }^{147}$ Vojniku Viviju Silvestru stelu (54) je postavila žena čije ime nije cijelo sačuvano. Od gentilicija je ostalo samo posljednje slovo $A$, a kognomen je najvjerojatnije bio Cinnamis, poznat na dva natpisa iz Salone i tipičan za oslobođenike. ${ }^{148}$ Vojnika Elija O[---] komemorirali su (55) Aurelije Sekundo i Aurelija Fortunata. U starijoj literaturi tumači se da je $L$ na početku 5. retka sigla Sekundova prenomena (Lucius). ${ }^{149}$ Zapravo je to brojka pedeset, broj godina koje je navršio pokojni vojnik. Desna strana stele je oštećena tako da se ne može reći u kakvom su odnosu s pokojnikom bili Sekundo i Fortunata. ${ }^{150}$ Vojnik Aurelije Januarije, otac, i majka Aurelija Ursina postavili su stelu (56) kćeri Aureliji Januariji koja je preminula s tri godine i 10 mjeseci. Velika većina dalmatinskih potvrda kognomena Ianuarius potječe iz Salone. ${ }^{151}$ Vojnik Licinije postavio je nadgrobni natpis (57) nećakinji Filenidi. Njezin je kognomen grčkoga podrijetla, vrlo rijedak i u zapadnim provincijama poznat u još nekoliko primjera. ${ }^{152}$ Sin duplikarij Gaj Alazinije Sekundin i kći Alazinija Kvintina komemorirali su (58) Gaja Alazinija Sekunda koji je preminuo u 87. godini života. Stela je pronađena u Klapavicama pored Klisa odakle potječe i nadgrobni natpis (59) koji je centurion Alazinije Valentin postavio roditeljima. Oba spomenika bi se mogla datirati u 2. stoljeće. Familija je vjerojatno dalmatinskog podrijetla. ${ }^{153}$

Dva natpisa spominju pripadnike Prve delmatske tisućnićke kohorte (Cohors prima milliaria Delmatarum). ${ }^{154}$ Vojnik Suro Viktorin postavio je stelu (60) hospiti

\footnotetext{
144 ALFÖLDY 1969: 214.

145 WILKES 1969: 149.

146 ALFÖLDY 1969: 273-276.

147 OPEL III: 70, Maximius.

148 ALFÖLDY 1969: 176.

149 BULIĆ 1885: 67, br. 190; CIL III 8728.

150 Detaljnije o restituciji natpisa MATIJEVIĆ 2015a: 290-291.

151 ALFÖLDY 1969: 317.

152 ALFÖLDY 1969: 262, OPEL III: 137, Philenis.

153 DEMICHELI 2016: 113-114.

154 Za dataciju v. MATIJEVIĆ 2015a: 73.
} 
Aureliji Terenciji koja je umrla s 37 godina. Terentius je uobičajen kao gentilicij, a kao kognomen osobito je čest u južnoj Galiji i keltskim predjelima. ${ }^{155}$ Aurelije Akvila postavio je nadgrobni natpis (61) centurionu Titu Aureliju Apoloniju i trgovcu Aureliju Flavu rodom iz Sirije (natione Surus), koji su preminuli u Sirmiju, i njihovom prijatelju Aureliju Lucijanu. Akvila je Apolonijev otac. Natpis započinje dativom „Titu Aureliju Apoloniju, njegovome bratu“ (Tito Aurelio Apollonio fratri eius) što, uz izostanak formule Dis manibus, može značiti da je postojao još jedan natpis koji je prethodio ovome i spominjao još jednog Akvilinog potomka. ${ }^{156}$ Kognomen Lucianus u Dalmaciji je zabilježen gotovo isključivo u Saloni, poznat je u Italiji, zapadnim i sjevernim provincijama. ${ }^{157}$ Kognomen Aquila posvuda je rasprostranjen, posebno u Italiji i Galiji, iz Dalmacije potječe nekoliko potvrda. ${ }^{158}$

Šest natpisa (T. I., 62.-67) pripada nižerangiranim pripadnicima namjesnikova oficija. ${ }^{159}$ Strator Stacilije Pulher komemorirao (62) je ženu Zosimu. Ime sugerira njezino orijentalno i oslobođeničko porijelo, a gotovo sve njegove dalmatinske potvrde dolaze iz Salone. ${ }^{160}$ Na steli (63) stratora Aurelija Hilarijana spomenuta je još jedna muška osoba, možda komemorator, od čijeg je imena sačuvan samo kognomen Kandid. Posvuda je raširen, a u Dalmaciji brojnošću potvrda prednjači Salona. ${ }^{161}$ Supruga Septijena Marcija postavila je stelu (64) stratoru Juliju Krispinu Pasaru. Ona je zasada jedini nositelj ovoga gentilicija u Dalmaciji i italskoga je podrijetla. ${ }^{162}$ Supruga Ticija Valentina komemorirala je singulara Aurelija Dizu (65). Gentilicij Titius posvuda je rasprostranjen, a ona bi mogla biti potomak Italika iz doba ranoga principata. ${ }^{163}$ Kognomen je također u Dalmaciji obilno zastupljen, posebice tijekom kasnog principata. ${ }^{164}$ Opcion konjanika singulara Aurelije Prisko postavio je nadgrobni natpis (66) sinu Aureliju Prisku koji je umro s dvije godine i osam mjeseci. Na ulomku nadgrobnog natpisa (67) spomenut je singularov sin od čijeg je pokraćenog kognomena sačuvano [---]and, što je vjerojatni drugi slog kognomena Amandianus, Amandinus ili Amandus koji su potvrđeni u Saloni tijekom kasnog principata. ${ }^{165}$

\footnotetext{
155 ALFÖLDY 1969: 307.

156 DEMICHELI 2015: 67.

157 ALFÖLDY 1969: 34, OPEL III: 34, Lucianus.

158 ALFÖLDY 1969: 155, OPEL I: 70, Aquila.

159 Za dataciju natpisa stratora MATIJEVIĆ 2015a: 153-155; za dataciju natpisa singulara MATIJEVIĆ 2016: 201-204.

160 ALFÖLDY 1969: 332, OPEL IV: 191, Zosimus.

161 ALFÖLDY 1969: 170, OPEL II: 30-31, Candidus.

162 ALFÖLDY 1969: 119, OPEL IV: 69, Septienus.

163 ALFÖLDY 1969: 127-128, OPEL IV: 124, Titius.

164 ALFÖLDY 1969: 320, OPEL IV: 140-141, Valentinus.

165 ALFÖLDY 1969: 146-147.
} 
Iz istoga su razdoblja dvije stele mornara mizenskog brodovlja. Slova [---] CTORI u 7. retku djelomično sačuvane stele (68) mornara [Ce]releja Muzeja mogla bi biti ostatak kognomena muške ili ženske osobe. U obzir mogu doći Victor odnosno Victoria ili neka od njihovih izvedenica (Victoricus, Victorinianus, Victorinus) koje su obilno potvrđene u Saloni iz doba kasnog principata. ${ }^{166}$ Slova CARE[---] u 8. retku možda su početni dio kognomena Carelaus koji je također, ali samo jedanput, potvrđen u Saloni. ${ }^{167}$ Najvjerojatnije su kognomeni pripadali dvama komemoratorima čiji su gentiliciji bili uklesani na lijevoj strani stele koja nedostaje. Pripadnik iste mornarice Julije Marcijan postavio je nadgrobni natpis (69) supruzi Juliji Krescentini i kćeri Juliji Marciji koja je preminula s osam godina. ${ }^{168}$ Krescentina nosi latinski kognomen koji je u Dalmaciji potvrđen samo nekoliko puta $\mathrm{i}$ to iz vremena kasnog principata, ${ }^{169} \mathrm{i}$ ima građansko pravo, kao i njihova kći čiji je kognomen tipičan za doba kasnog principata i u Dalmaciji poznat isključivo iz Salone. ${ }^{170}$

\section{I.3. Osobe s natpisa aktivnih pripadnika neodredivih postrojbi} (T. I., 70-75)

$\mathrm{Na}$ šest oštećenih natpisa spominju se aktivni vojnici, ali se ne može odrediti kojoj su postrojbi pripadali. U razdoblju je ranog principata Titul, konjanik nepoznate postrojbe, postavio nadgrobni natpis (70) ženi Kordiji K[---] i nekoj Sekundi koja je njegovoj ženi bila nešto u rodu, možda sestra, majka ili kći. Kognomen posljednje spomenute osobe započinje sa Secun[---], a može biti neka od izvedenica kognomena Secundus odnosno Secunda ${ }^{171}$ Gentilicij Cordius italskog je podrijetla i u Dalmaciji potvrđen s nekoliko primjera. ${ }^{172}$

Majka Elija Maksimina komemorirala je konjanika neke kohorte Lucija Veturija (71), vjerojatno oko sredine 2. stoljeća. ${ }^{173}$ Opcion Gaj Memije Hijerak postavio je nadgrobni natpis (72) bratu koji je živio 30 godina, a ime mu nije sačuvano. Na početku retka, odmah nakon crte loma, vjerojatno je bila uklesana brojka dvanaest $(X I I)$, možda godine bratove vojne službe. Na ulomku nadgrobnog natpisa (73) spominju se tri različite osobe s gentilicijem Helvius. Slova $V F$ u 2. retku mogu

\footnotetext{
166 Victoricus, Victorinianus, Victorinus, v. ALFÖLDY 1969: 326-328.

167 ALFÖLDY 1969: 171.

168 Za dataciju oba natpisa v. MATIJEVIĆ 2015a: 77-78.

169 ALFÖLDY 1969: 182, OPEL II: 84, Crescentinus.

170 ALFÖLDY 1969: 238.

171 ALFÖLDY 1969: 290-292, za dataciju v. MATIJEVIĆ 2015a: 79.

172 ALFÖLDY 1969: 77-78, OPEL II. 75, Cordius.

173 Za dataciju v. DEMICHELI 2013: 84.
} 
se razriješiti kao vivus ili viva fecit za čime je mogla slijediti česta sintagma sibi et što je potvrđeno na mnogim natpisima iz Salone. ${ }^{174} \mathrm{Uz}$ takvu restituciju treba pretpostaviti da se u izgubljenim retcima spominjala najmanje još jedna osoba. U 3. retku je sačuvan samo početak gentilicija Helv[---] pa se ne može reći je li osoba muško ili žensko. Imajući na umu predloženu restituciju 2. retka, bila bi to osoba kojoj je spomenik podignut. Međutim, sigurno je bio podignut i dvjema muškim osobama čija su imena u 4. i 6. retku. Prvi je bio vojnik i zvao se Tit Helvije [---], a drugi se zvao Tit Helvije S[---]. Gentilicij je italskog podrijetla, ali čest i u Narbonskoj Galiji te Hispaniji. ${ }^{175}$ Vojnik [---]ije Lici[nije(?)]postavio je stelu (74) djetetu koje je preminulo s 14 godina i još jednoj osobi. ${ }^{176}$ Nekom vojniku pripada teško oštećen natpis (75) koji je između 1. i 3. stoljeća podigao njegov oslobođenik i nasljednik. ${ }^{177}$

\section{II.1. Osobe s natpisa legijskih veterana}

$$
\text { (T. II., 76. - 126) }
$$

Četiri natpisa veterana Sedme legije i jedan veterana Jedanaeste legije raniji su od 42. godine (T.II. 76-80). Pinarija, oslobođenica Gaja Pinarija Skarpa, postavila je stelu (76) njemu i njegovome sinu čije ime nije sačuvano. ${ }^{178}$ Hortenzija Kvarta i Lucije Korelije Jukundo postavili su nadgrobni natpis (77) Kvintu Hortenziju kojega nazivaju ocem. Jukundo nema veteranov gentilicij što bi moglo značiti da je bio dijete iz nezakonite veze, ${ }^{179}$ da je rođen dok je Hortenzije bio aktivni vojnik pa je dobio majčin gentilicij, ili da je njezino dijete iz neke prethodne veze. Gentilicij Corellius italskog je podrijetla, a Jukundo je u Dalmaciji zasada jedini njegov nositelj iz doba ranog principata. ${ }^{180}$ Rutilija je postavila nadgrobni natpis ocu Aulu Rutiliju Tusku, sestri Rutiliji Fes[---] i bratu (78). Natpis je znatno oštećen s desne strane jer je u 1. retku iza Rutilijinog gentilicija moralo biti dovoljno mjesta da se ukleše njezin kognomen. Nigdje u literaturi nema pokušaja restitucije očevog i bratovog imena. ${ }^{181}$ No, Tuskov gentilicij mora biti Rutilius jer je to gen-

174 Izbor primjera samo iz Salone: ILIug 2162, 2198; CIL III 2083, 2197, 2257, 2483, 2491, 2605, $8583,8638,8786,8788,8807,8970,9098,9126,9392,12924,14280,14777.1$, a treba im dodati i vojničke natpise br. $81,82,84,85$ citirane u ovome radu.

175 ALFÖLDY 1969: 89, OPEL II: 176, Helvius.

176 Za dataciju natpisa br. 72 i 73 v. MATIJEVIĆ 2015a: 79.

177 Ulomak je neobjavljen. Osnovni podatci nalaze se u MATIJEVIĆ 2015a: 634, kat. br. 231. Za dataciju spomenika br. 74. i 75 iz ove skupine MATIJEVIĆ 2015a: 292.

178 MATIJEVIĆ 2015b: 134.

179 CAGNAT 1914: 72, SANDYS 1919: 216.

180 ALFÖLDY 1969: 78, OPEL II: 75, Corellius.

181 CIL III 9711; Eph. ep. 4, 343; BETZ 1938: 67, br. 74, TONČINIĆ 2011: 106, kat. br. 77, EDH HD058594. 
tilicij njegove kćeri. Prema tome, na kraju 2. retka slova $A R$ ne mogu nikako biti početak njegova gentilicija nego u njima treba prepoznati siglu prenomena Aulus i početak gentilicija Rutilius. Nakon Tuskovog imena i oznake legije spomenuta je još jedna muška osoba čije ime započinje siglom $A$, potom slijedi oštećenje i u početku 5. retka kognomen Primio. U sigli $A$ na kraju 4. retka bi trebalo prepoznati prenomen Aulus, a u slovu $F$ na kraju petoga retka početak imenice frater. To je u skladu s Rutilijinom ulogom komemoratorice koja podiže spomenik članovima obitelji. Ako je Aulus njezin brat tada je od oca naslijedio prenomen i gentilicij koji je bio ispisan u nastavku 4. retka. Na kraju se spominje još jedna ženska osoba s gentilicijem Rutilius, najvjerojatnije komemoratoričina sestra, druga Tuskova kći. Gentilicij Rutilius je italskog podrijetla, u Dalmaciji potvrđen s desetak primjera. ${ }^{182}$ Kognomen Primio posvuda je rasprostranjen, u Dalmaciji poznat s još jednog natpisa. ${ }^{183}$ Stanovita [---]ropena F[abr]icija postavila je za života stelu (79) Luciju Vegnoniju i sebi. Početna slova njezina gentilicija su oštećena te je teško reći kako je glasio. Neki autori misle da je gentilicij Tropaenus, ${ }^{184}$ inače nepoznat u rimskoj Dalmaciji, ${ }^{185}$ tako da ga drugi autori uopće ne spominju kao mogućnost. ${ }^{186}$ Kognomen je najvjerojatnije Fabricia ${ }^{187}$ Mogao bi to biti primjer inverznog imenovanja, ${ }^{188}$ to jest da se komemoratorica zvala Fabricia Tropaena odnosno Tryphaena. Gentilicij Fabricius potvrđen je u Dalmaciji, ${ }^{189}$ a kognomen bi mogao biti derivacija kognomena Tryphaenus potvrđenoga većinom u Italiji, ali i u Hispaniji. ${ }^{190}$ Nadgrobni natpis (80) Luciju Korneliju iz Jedanaeste legije postavili su sinovi čija imena nisu navedena.

Sedam natpisa veterana Sedme legije i četiri natpisa Jedanaeste legije i natpis jedne od ovih legija datiraju se nakon 42. godine (T.II., 81-92). Petorica veterana Sedme legije bila su komemoratori. Gaj Lolije Valent (81) imao je suprugu Hostiliju Sekundu, Publijevu kći. Njezin gentilicij upućuje na podrijetlo iz sjeverne Italije, a u Saloni nema drugih potvrda. ${ }^{191}$ Gaj Vacinije Kapiton postavlja spomenik (82) sebi i oslobođenici Vaciniji Felikuli. Njezin je kognomen čest kod oslobođeničke populacije u zapadnom dijelu Carstva. ${ }^{192}$ Marija Kvinta, čija filijacija Sp(uri) f(ilia)

\footnotetext{
182 ALFÖLDY 1969: 116, OPEL IV: 38, Rutilius.

183 ALFÖLDY 1969: 271, OPEL III: 159, Primio.

184 BULIĆ 1886: 9, br. 2, TONČINIĆ 2011: 96.

185 ALFÖLDY (1969: 129) ga uopće ne navodi pod gentilicijima koji počinju sa slovom $T$.

186 WILKES 2000: 337, br. 22, FERJANČIĆ 2002: 66.

187 ALFÖLDY 1969: 200.

188 O inverznom imenovanju v. KURILIĆ 2009: 164-165.

189 ALFÖLDY 1969: 84.

190 OPEL IV: 131, Tryphaena.

191 ALFÖLDY 1969: 90, OPEL II: 186, Hostilius.

192 ALFÖLDY 1969: 202.
} 
govori da se nije znalo tko joj je otac, bila je supruga Lucija Pescenija Saturnina (83). ${ }^{193}$ Gentilicij Marius italskog je podrijetla, ${ }^{194}$ kognomen Quintus čest je u Dalmaciji. ${ }^{195}$ Lucije Fabije Saturnin (84) komemorirao je oslobođenicu Klaudiju Euhu na mjestu koje mu je ustupio prijatelj Gaj Ticije Restitut. Njegovo ime upućuje na italsko podrijetlo. ${ }^{196}$ Euha je slobodu dobila od Tiberija Klaudija Alipa čija „libertinska filijacija“ (l(iberti) Caesaris), prenomen i gentilicij govore da je bio oslobođenik cara Klaudija. ${ }^{197}$ Euha je najvjerojatnije bila Saturninova žena ili suložnica. ${ }^{198}$ Gaj Lukrecije postavio je stelu (85) sebi, oslobođenicama Firmili i Tihe te sinu Provincijalu i svima svojima pri čemu je očito mislio na ostale članove familije. Imena Firmilla i Tyche tipična su za oslobođeničku populaciju u zapadnom odnosno istočnom dijelu Carstva. ${ }^{199}$ Kognomen Provincialis posvuda je rasprostranjen, ali je tipičan za keltska područja. ${ }^{200}$ Pretpostavlja se da je ovaj veteran bio brat gore spomenutoga signifera Gaja Lukrecija (7) koji je na natpisu spomenuo brata, ali nije naveo njegovo ime. Signifer je preminuo tijekom službe, a ovaj je brat dočekao status veterana. ${ }^{201}$ Arija Agatemerida i Kvint Arije Prisko(?) postavili su za života stelu (86) njezinome suprugu (coniux), veteranu Gaju Auliju Sekundu. Istovjetni gentilicij upućuje na pretpostavku da je Arije Prisko(?) bio njezin otac, brat ili patron. Gentilicij Arrius italskog je podrijetla, u Dalmaciji obilno potvrđen, a sve njegove potvrde iz doba kasnoga principata potječu iz Salone, uključujući i jednu iz Sikula. ${ }^{202}$ Kognomen Agathemeris grčkoga je podrijetla, čest na natpisima iz Rima i to većinom među robovima i oslobođenicima. ${ }^{203}$ Arijev je kognomen najvjerojatnije Priscus, jedan od najraširenijih u Carstvu i Dalmaciji gdje je popularan među domaćim stanovništvom. ${ }^{204}$ Upravo nadgrobni natpis iz Sikula može poslužiti kao dokaz da su potomci ove familije tijekom kasnog principata bili vlasnici zemlje u zapadnom dijelu salonitanskog agera odakle potječe Aulijeva stela. ${ }^{205}$ Tit Oktavije Hister oporučno je postavio stelu (87) sebi i kontubernalu Akrinu. Izraz contubernalis pojavljuje se uz ime kolege iz iste ili druge jedinice, a

\footnotetext{
$\overline{193}$ MATIJAŠIĆ $2002: 59,75$.

194 ALFÖLDY 1969: 98, OPEL III: 59, Marius.

195 ALFÖLDY 1969: 280, OPEL IV: 20, Quintus.

196 Za gentilicij Titius i kognomen Restutus v. ovdje bilj. 163, 82

197 O ovakvim i sličnim načinima izražavanja oslobođeničkog statusa v. WEAVER 1972: 49 i d.

198 MATIJEVIĆ 2015b: 135-136.

199 ALFÖLDY 1969: 203, 315.

200 ALFÖLDY 1969: 276, OPEL III: 169, Provincialis.

201 MIHĂILESCU-BÎRLIBA 2006: 243, br. 326.

202 ALFÖLDY 1969: 61.

203 DEL HOYO 2000: 319, v. i SOLIN 2002: 4-7.

204 ALFÖLDY 1969: 273, OPEL III: 163, Priscus.

205 MATIJEVIĆ 2017b: 126-136.
} 
upotrebljava se i za osobe koje nemaju veze s vojskom. Acris je kognomen grčkoga podrijetla i nema drugih potvrda u Dalmaciji, kao ni u provincijama sjevernog i zapadnog dijela Carstva. ${ }^{206}$ Neki natpisi iz Italije pokazuju da je tipičan upravo za oslobođenike, ${ }^{207}$ pa bi se moglo pretpostaviti da je i ovo osoba takvog statusa. Smije li se suditi prema njegovom imenskom obrascu, Akrin nema građansko pravo te je mogao biti i rob. Tako je, primjerice, s Helijem (51) i Hermetom (94), ali nije isključeno ni da su to oslobođenici čiji je gentilicij ispušten. ${ }^{208} \mathrm{~S}$ druge strane, katkada se i članovi najuži obitelji navode samo kognomenom. Tako je veteran Gaj Lukrecije (85) spomenuo sina Provincijala. Barbija Paula postavila je stelu (88) ocu, veteranu Luciju Barbiju I[---], majci Kvintiji i kćeri Silvini koja je umrla s 18 godina. Paulin je kognomen čest u Dalmaciji tijekom ranog principata, također u Italiji i zapadnim provincijama. ${ }^{209}$ Majka nosi jednočlano ime, najvjerojatnije gentilicij koji upućuje na podrijetlo iz sjeverne Italije. ${ }^{210}$ Kognomen Pauline kćeri Silvine poznat je u Dalmaciji i tipičan za provincije na zapadu. ${ }^{211}$ Nerija Pijerida postavila je stelu (89) suprugu, veteranu nepoznatog imena. Ovo je u Dalmaciji zasad jedina potvrda njezinoga gentilicija italskog podrijetla iz vremena ranoga principata, a ni u drugim dijelovima Carstva nije čest. ${ }^{212}$ Kognomen također nije osobito čest, iako iz Salone i šire okolice potječe nekoliko primjera. ${ }^{213}$ Oslobođenik Valerije I[---] postavio je nadgrobni titul (90) svome patronu Gaju Valeriju [---]. ${ }^{214}$ Na nadgrobnom natpisu (91) veterana [---]reli[ja ---] sačuvan je kognomen Jovencija(?) prije kojega je navedena filijacija što sugerira da je imala građansko pravo i imenski obrazac poput Julije Pole (8) i Hostilije Sekunde (81). Najvjerojatnije je bila veteranova žena i njegova komemoratorica. Pripadnik Sedme ili Jedanaeste legije postavio je natpis (92) sebi i svojima (sibi et suis).

Tit Fuficije iz Dvadesete valerijevske pobjedničke legije (Legio vicesima Valeria victrix) postavio je u Klaudijevo doba luksuznu stelu (93) sebi, ženi, sinu i kćeri čije portrete u gornjem dijelu spomenika ne prati natpis, te su njihova imena nepoznata. ${ }^{215} \mathrm{U}$ donjem dijelu su portreti oslobođenika Tita Fuficija Privata i oslobođenicâ Fuficije Priske i Fuficije Prime. Privato i Prima su Titovi oslobođenici, a Priska je

\footnotetext{
$\overline{206}$ ALFÖLDY 1969: 141, OPEL I: 20, Acris.

207 CIL VI, 7059; 24853; $A E$ 1985, 249; CIL XI, 3321.

208 ROSS TAYLOR 1961: 117, bilj. 13.

209 ALFÖLDY 1969: 261, OPEL III: 129-130, Paulus.

210 ALFÖLDY 1969: 114; OPEL IV: 19-20, Quintius.

211 ALFÖLDY 1969: 298; OPEL IV: 83, Silvinus.

212 ALFÖLDY 1969: 102, OPEL III: 99, Nerius.

213 ALFÖLDY 1969: 264, OPEL III: 141, Pieris.

214 MATIJEVIĆ 2015: 136.

215 Za dataciju v. CAMBI 2000: 44-45, kat. br. 50, tab. 62 .
} 
oslobođenica neke žene. Ovo je jedini natpis iz korpusa koji poimenice spominje više oslobođenika. ${ }^{216}$ Marko Antonije Suro iz Četvrte flavijevske legije oporučno je dao postaviti stelu (94) članovima obitelji te oslobođenicima i oslobođenicama. Najprije je spomenuta njegova žena Pazija Prima, potom skraćenice lib. lib. i na kraju neki Hermet. Ovo je zasada jedina potvrda gentilicija Pasius u europskom dijelu Carstva, a Prima bi mogla biti domorodačkog podrijetla. ${ }^{217}$ Hermes je ime grčkog podrijetla i tipično za osobe robovskog i oslobođeničkog statusa. ${ }^{218}$ August je zakonom Fufia Caninia iz 2. pr. Krista ograničio broj robova koje je gospodar, u odnosu prema ukupnom broju robova u svom vlasništvu, smio oporučno osloboditi. ${ }^{219}$ Prema tome nije neobično što gospodari nisu svim robovima dali slobodu i što se imena nekih katkada nalaze na nadgrobnim natpisima. ${ }^{220}$ Marku Utediju Salubijanu Gaju Petiliju Amandu iz Četrnaeste dvojne legije natpis (95) je postavila supruga Petilija Sekundina između ranoflavijevskog doba i sredine 2. stoljeća. ${ }^{221}$ Ona je italskog podrijetla ${ }^{222}$ i kći Gaja Petilija Amanda. Veteranovo polinimijsko imenovanje otkriva da ga je adoptirao punac, vjerojatno također politički aktivan i član ugledne salonitanske familije, što mu je omogućilo političku karijeru u provincijskoj metropoli. ${ }^{223}$

Šest legijskih veterana zabilježeno je na natpisima iz razdoblja kasnog principata (T. II., 96-101). Trojica veterana i bivših beneficijarija služila su u Desetoj dvojnoj legiji. Gaj Julije Dolent i Celija Bonoza postavili su sebi nadgrobni žrtvenik (96) sredinom 2. stoljeća. ${ }^{224}$ Gentilicij Caelius italskog je podrijetla, a kognomen bi mogao upućivati na afrički dio Carstva. ${ }^{225}$ Bonoza je najvjerojatnije bila Dolentova žena. Ticija Mirsina postavila je nadgrobni natpis (97) mužu Luciju Tituleniju Respektu, vjerojatno u drugoj polovici 2 . stoljeća. ${ }^{226}$ Ona je vjerojatno potomak italskih Ticija, dok je grčki kognomen Myrsine vrlo rijedak. ${ }^{227}$ [Mar]cija(?) Vi[ktori]na(?) komemorirala je (98) supruga Valerija V[alen]ta(?). Njezino je ime dosta oštećeno, ali bi se moglo pretpostaviti da je gentilicij bio Marcius, a kognomen Victorina. ${ }^{228}$ Spomenuta je i [Vale(?)]rija T[---], ${ }^{229}$ najvjerojatnije njihova kći.

\footnotetext{
$\overline{216}$ MATIJEVIĆ $2015 \mathrm{~b}: 137$.

217 ALFÖLDY 1969: 107, OPEL III: 126, Pasius.

218 ROSS TAYLOR: 1961, 125; ALFÖLDY 1969: 215.

219 WESTERMANN 1955: 89, TEMIN 2004: 531.

220 MATIJEVIĆ 2015b: 137.

221 Za dataciju v. MATIJEVIĆ 2015a: 102.

222 ALFÖLDY 1969: 108.

223 MATIJEVIĆ 2020.

224 Za dataciju v. CAMBI 2005: 101-102.

225 ALFÖLDY 1969: 68, 166.

226 Za dataciju v. MATIJEVIĆ 2012b: 73.

227 ALFÖLDY 1969: 250, OPEL III: 93, Myrsine.

228 ALFÖLDY 1969: 97-98, 327-328.

229 Za dataciju v. MATIJEVIĆ 2015a: 140.
} 
Na fragmentiranoj steli (99) Lucija Domicija Valenta iz Pete makedonske legije spominju se još četiri osobe čija imena nisu sačuvana cijela, a nema ni odrednice krvne ili neke druge veze. ${ }^{230}$ Iza Valentovog imena na kraju 4. retka i poslije veznika et je slovo $A$ kojim možda počinje ime druge osobe kojoj je stela podignuta. Mogao bi to biti prenomen Aulus, iako se vjerojatnijim čini da je to prvo slovo gentilicija ženske osobe, Valentove supruge. Dvije osobe nose gentilicij jednak veteranovom, a njihova imena sačuvana su u 7. retku (Domiti[us(?) ---]) i 8. retku (C(aius) Domi[tius ---]). Druga je osoba muškarac, a spol prve se ne može odrediti. Vjerojatno su u nekom srodstvu s veteranom i možda su upravo njegova djeca. Pretpostavka da se u 4. retku spominje Valentova žena time je još izglednija. U 6. retku spomenut je Gaj Ofonije [---] za kojega se ne može reći u kakvoj je vezi s osobama na natpisu. Gentilicij Offonius italskog je podrijetla i izrazito rijedak. ${ }^{231}$ Također se ne može odrediti tko je komemorator, iako je to najvjerojatnije sâm veteran Valent.

Venerija Kvartila komemorirala je (100) supruga Aurelija Materna iz Druge italske legije (Legio secunda Italica) ${ }^{232} \mathrm{Njezin} \mathrm{je} \mathrm{gentilicij} \mathrm{južnoitalskog} \mathrm{podrijetla}$ i općenito rijetko zastupljen. ${ }^{233}$ Kognomen je posvuda rasprostranjen, u Dalmaciji je potvrđen isključivo na natpisima iz Salone. ${ }^{234}$ Marko Veracije Sever iz Tridesete ulpijevske pobjedničke legije (Legio tricesima Ulpia victrix) za života je postavio nadgrobni natpis (101) sebi, ženi Liciniji i sinu Marku Veraciju Severinu koji je umro s pet godina. ${ }^{235}$ Kognomen Licinius posvuda je rasprostranjen, u Dalmaciji potvrđen i kod domaćeg stanovništva. ${ }^{236}$

\section{II.2. Osobe s natpisa veterana pomoćnih postrojbi i mornaričkih veterana}

$$
\text { (T. II., 102-115) }
$$

Pet natpisa potječe iz doba ranog principata. Oslobođenik i nasljednik Magno podigao je nadgrobni žrtvenik (102) Gaju Juliju Mari iz Druge kohorte Kiresta (Cohors secunda Cyrrhestarum) ${ }^{237}$ Magnov je kognomen posvuda rasprostranjen, posebno u Italiji. ${ }^{238}$ Natpis je iz sredine 1. stoljeća i najraniji je epigrafski spomen nekog dalmatinskog augzilijara koji je imao oslobođenika. ${ }^{239}$ Misicij Virdomar iz

\footnotetext{
230 Za dataciju v. MATIJEVIĆ 2015a: 102-103.

231 ALFÖLDY 1969: 105, OPEL III: 111, Offonius.

232 Za dataciju v. MATIJEVIĆ 2015a: 104.

233 ALFÖLDY 1969: 134, OPEL IV: 154, Venerius.

234 ALFÖLDY 1969: 278, OPEL IV: 15, Quartillus.

235 Za dataciju v. MATIJEVIĆ 2015a: 103.

236 ALFÖLDY 1969: 231, OPEL III: 26, Licinius.

237 Za dataciju v. MATIJEVIĆ 2009: 38-39.

238 ALFÖLDY 1969: 235-236.

239 MATIJEVIĆ: 2015a, 137.
} 
Nove klaudijevske ale (Ala Claudia nova) postavio je tijekom prvih godina Vespazijanove vladavine portretnu stelu (103) sebi i sestri Pami. Pripadali su narodu Bituriga koji je naseljavao Akvitansku Galiju. ${ }^{240}$ Pješak Venet otpušten je iz Treće kohorte alpinaca (104) godine 94. kada su građansko pravo dobili i Madena, kći Plarentova iz naroda Deramista, s kojom mu je dopušteno sklopiti brak, i njihov sin Gaj. Madenin narod obitavao je između Melkumana i Daorsa u današnjoj istočnoj Hercegovini. ${ }^{241} \mathrm{Na}$ kraju teksta stoje imena sedmorice svjedoka (testatores). Na diplomama izdanima poslije 73.-74. godine ne piše iz kojih su gradova potjecali, a tada je car Vespazijan dopustio da smiju svjedočiti državni službenici koji nisu morali osobno poznavati veterana. ${ }^{242}$ Tijekom vladavine cara Hadrijana oslobođenik i nasljednik Tit Flavije Eulog postavio je svojom voljom (ex voluntate sua) nadgrobni žrtvenik (105) patronu, bivšem visokorangiranom časniku carske konjaničke straže i centurionu Osme dobrovoljačke kohorte Titu Flaviju Luciliju. Eulogov je kognomen grčkoga podrijetla i tipičan za oslobođenike. ${ }^{243}$

Pet natpisa pripada augzilijarnim veteranima iz doba kasnoga principata. Novelija [---] je tijekom 2. stoljeća postavila nadgrobni natpis (106) mužu Luciju Juliju V[---] iz Osme dobrovoljačke kohorte, sebi i svojoj kognaciji. ${ }^{244}$ J. Medini vjeruje da pojam cognatio ovdje znači bliže srodnike supružnikâ koji, kako se čini, nisu imali vlastitog potomstva, te da isključuje oslobođenike i njihovo potomstvo koji su na natpisu obuhvaćeni izrazom lib(ertis) liberisque eorum. ${ }^{245}$ Novelijin gentilicij upućuje na podrijetlo iz sjeverne Italije, a u provinciji postoji samo još jedna njegova potvrda, također iz vremena kasnog principata. ${ }^{246}$ Silvan iz iste kohorte za života je postavio nadgrobni natpis (107) sebi, supruzi od čijeg je imena sačuvan samo završni dio [---]CAE i bratu čije ime nije sačuvano. Djeca i nasljednici, Aurelije Viktorin i Julija, podigli su urnu (108) Marku Aureliju Varonu iz Prve tisućnićke delmatske kohorte. Kognomen Victorinus posvuda je čest, posebno u Africi, Galiji, Panoniji, ali i u Dalmaciji. ${ }^{247}$ Kći je imenovana kognomenom koji je posebno rasprostranjen u galskim i germanskim provincijama. ${ }^{248}$ Antistija Anterotova komemorirala je na steli (109) supruga Publija Domicija Potenta iz Treće

\footnotetext{
240 MARŠIĆ: 2015, 11, 18.

241 BOJANOVSKI 1988: 110-112

DEMICHELI 2012: 14. Svjedoci na Venetovoj diplomi su Aulo Volumnije Ekspektat, Kvint Orfije Kupit, Gnej Egnacije Vital, Sekst Manlije Cinamije, Lucije Pulije Sperat, Publije Atinije Amermnije i Lucije Pulije Verekundo.

243 FAURE 2010: 236.

244 Za dataciju v. MATIJEVIĆ 2015b: 140.

245 MEDINI 1985: 16. Za pojam cognatio v. i KURILIĆ 2008: 47.

246 ALFÖLDY 1969: 103, OPEL III: 105, Novellius.

247 ALFÖLDY 1969: 327-328, OPEL IV: 168-169, Victorinus.

248 ALFÖLDY 1969: 224, OPEL II: 200, Iulius.
} 
kohorte alpinaca. Njezin je kognomen izveden iz gentilicija italskog podrijetla Antistius ${ }^{249}$ a patronimik (Anteros) je posebno raširen kod robovske populacije i poznat u drugim krajevima Carstva. ${ }^{250}$ Flavija Tercija postavila je nadgrobni natpis (110) suprugu, singularu Gaju Sabiniju Nikijatu. Ona nosi carski gentilicij Flavius, izrazito rasprostranjen u Dalmaciji kao i u Saloni, što vrijedi i za njezin kognomen. ${ }^{251}$ Sempronija Marcelina komemorirala je (111) supruga singulara Valerija Valentina, čiji gentilicij ${ }^{252}$ i kognomen upućuju na italsko podrijetlo. ${ }^{253}$

Četiri spomenika svjedoče o životnim suputnicima mornaričkih veterana iz razdoblja ranog principata. Na diplomi (112) centuriona Platora, sin Venetova, iz 71. godine navedena su imena sedmorice svjedoka i gradovi iz kojih su potjecali. Na diplomama prije 73-74. godine svjedoci su isticali podrijetlo i osobno su poznavali veterana. ${ }^{254}$ Dvojica su potjecala iz Salone. Vitez (eques Romanus) Tit Julije Ruf mogao je imati određeno vojno iskustvo u legiji ili u nekoj pomoćnoj postrojbi rimske vojske. Mnogo više se može reći o Publiju Ceteniju Klementu čiji je nadgrobni natpis pronađen u koloniji Skupi u Gornjoj Meziji. ${ }^{255}$ On je kao veteran Sedme legije umro u 70. godini života, u aktivnoj je službi proveo 21 godinu što znači da je kao veteran živio prilično dugo - između 20 i 30 godina. Otpušten je ranije nego je bilo uobičajeno pa se smatra da je posrijedi bila neka ozljeda (missio causaria) ili posebna zasluga. Klement je premino u zadnjoj četvrtini 1. stoljeća, a u legiju bio primljen dok je boravio u Dalmaciji. Najvjerojatnije je svjedočio kao veteran. Plator je najvjerojatnije diplomu primio u Italiji gdje je mogao upoznati Rufa i Klementa, iako nije isključeno ni da se to dogodilo u Dalmaciji, možda u Saloni. U Saloni su Klement i Plator mogli boraviti kao aktivni vojnici jer su ovdje potvrđeni vojnici Sedme legije i kombiniranog odjeljenja mizenske i ravenske ratne mornarice. Ruf je također mogao biti pripadnik Sedme legije. Možda su ostala petorica svjedoka čija su imena navedena na kraju isprave pripadala nekoj vojnoj postrojbi tada smještenoj u Dalmaciji: Tit Fanije Celer, Gaj Marcije Prokul i Kvint Poblicije Krescencije iz Jadera, Publije Lurije Moderat iz Rizinija, i vitez Publije Vibije Maksim iz Epidaura. ${ }^{256}$

\footnotetext{
$\overline{249}$ ALFÖLDY 1969; 59, 151, OPEL I: 58, Anthis.

250 ALFÖLDY 1969: 151, OPEL I: 58, Anteros.

251 ALFÖLDY 1969: 38-41, 307-308.

252 ALFÖLDY 1969: 119, OPEL IV: 64, Sempronius.

253 ALFÖLDY 1969: 236-237, OPEL III: 53-54, Marcellinus. Za dataciju ovih pet natpisa v. MATIJEVIĆ 2015a: 109, 112-113, za dataciju dvaju singularskih natpisa v. MATIJEVIĆ 2016: 202, 204

254 DEMICHELI 2012: 14

255 ILIug 34: P(ublius) Caetenni/us P(ubli) f(ilius) Clemens / Salon(is) vet(eranus) leg(ionis) VII / C(laudiae) p(iae) f(idelis) milit(avit) annis XXI \& vixit annis $L X X / h$ (ic) s(itus) e(st) / P(ublius) Caetennius Felici(anus) / libert(us) et heres / f(aciendum) c(uravit).

256 DEMICHELI 2012: 49-51. Za Julija Rufa i Vibija Maksima v. i WILKES 1970: 535.
} 
Trojica mornaričkih veterana pokopana su u Saloni tijekom kasnog principata. Sekstilija Rufina postavila je nadgrobni natpis (113) roditeljima, veteranu Luciju Sekstiliju Rufu iz mizenske mornarice i Papiriji Helpidi, te Sekstiliji Valeriji, najvjerojatnije sestri. Gentilicij njezine majke italskog je podrijetla, ${ }^{257}$ dok je grčki kognomen Elpis većinom svojstven oslobođenicima. Velika većina dalmatinskih potvrda potječe iz Salone, razmjerno je čest na zapadu. ${ }^{258}$ Marku Dioniziju Firmu iz ravenske mornarice nadgrobni natpis (114) postavio je istoimeni sin. Njihov gentilicij upućuje na orijentalno podrijetlo. ${ }^{259}$ Flaviju Zenonu stelu (115) je postavio sin Zenon ${ }^{260}$ čiji kognomen, u kontekstu s grčkim pismom ovoga nadgrobnog natpisa, također jasno govori za njegovo orijentalno podrijetlo. ${ }^{261}$

\section{II.3. Osobe s natpisa veterana iz neodredivih postrojbi}

$$
\text { (T. II.3., 116.-126) }
$$

Oktavija Rufina postavila je sarkofag (116) mužu Luciju Apuleju Montanu. Njezin je gentilicij posvuda rasprostranjen, posebno u sjevernoj Italiji, dok su u Dalmaciji tijekom kasnoga principata njegovi nositelji i Orijentalci. ${ }^{262}$ Većina dalmatinskih potvrda Rufinina kognomena potječe iz Salone. ${ }^{263}$ Kći Elija Prokulina i oslobođenik i nasljednik Elije Urban postavili su sarkofag (117) Publiju Eliju Prokulinu. ${ }^{264}$ Urbanov je kognomen tipičan upravo za oslobođenike u zapadnom dijelu Carstva. ${ }^{265}$ Oslobođenici Gaj Nertonije Filokirije i Gaj Nertonije Krizant podigli su nadgrobni žrtvenik (118) Gaju Nertoniju Speratu. ${ }^{266}$ Njihovi su kognomeni grčki i tipični za oslobođenike iz istočnog dijela Carstva. ${ }^{267}$ Elija Mesijana postavila je sarkofag (119) Aureliju Saturninu i sebi. ${ }^{268} \mathrm{~S}$ njom je živio 37 godina i bio je njezin partner (compar), odnosno muž jer se ova imenica također upotrebljavala za supružnike u zakonski priznatom braku. ${ }^{269}$ Kognomen Messiana

\footnotetext{
V. bilj. 50, 51.

ALFÖLDY 1969: 192, OPEL II: 116, Elpis.

59 ALFÖLDY 1969: 188-189.

260 Za dataciju natpisa ove trojice mornaričkih veterana v. MATIJEVIĆ 2015a: 114.

261 ALFÖLDY 1969: 332.

262 ALFÖLDY 1969: 104-105, OPEL III: 110-111, Octavius.

263 ALFÖLDY 1969: 283.

264 Oba spomenika potječu iz kraja 2. ili početka 3. stoljeća, v. CAMBI 2010: 36-37, 42-43.

265 ALFÖLDY 1969: 316, v. MATIJEVIĆ 2015b: 142.

266 Prema tipu spomenika datacija natpisa bi možda mogala biti proširena i na prvu polovicu 2. stoljeća, v. MATIJEVIĆ 2015a: 116.

267 ALFÖLDY 1969: 176, 263.

268 Sarkofag se datira u 3. stoljeće, v. CAMBI 2010: 42-43.

269 PHANG 2001: 199.
} 
i njegova rasprostranjenost upućuju na dalmatinsko podrijetlo. ${ }^{270}$ Pripadala je familiji koja je civitet mogla dobiti u doba cara Hadrijana.

Skupina od sedam natpisa potječe iz doba kasnoga principata. ${ }^{271}$ Kanija Ursina postavila je stelu (120) suprugu Marku Atiju Verekundijanu. Spomenuta je i na natpisu iz Podstrane. ${ }^{272}$ Kaniji iz Salone i okolice su italskog podrijetla. ${ }^{273}$ Velika većina dalmatinskih potvrda kognomena Ursinus u vremena kasnog principata je iz Salone i okolice. ${ }^{274}[\mathrm{Be}(?)] n i j a$ Kalitiha postavila je stelu (121) suprugu Valeriju Prokulu. Nije isključeno da je gentilicij bio Ennius koji je epigrafski potvrđen u Dalmaciji i Saloni. ${ }^{275}$ Kalitihin je kognomen posvuda rasprostranjen, posebno $\mathrm{u}$ Italiji, dok je u Dalmaciji ovo tek njegova druga potvrda. ${ }^{276}$ Klaudija Nigrina komemorirala je supruga (122) Valerija Frontona. Njezin je kognomen posvuda rasprostranjen, posebice u keltskim provincijama. ${ }^{277}$ Aurelija Kalista postavila je nadgrobni natpis (123) mužu Sestiju Nepotu i sebi. Njezin je kognomen posvuda rasprostranjen, a gotovo sve dalmatinske potvrde iz kasnoga principata dolaze iz Salone. ${ }^{278}$ Neka treća osoba čije ime nije sačuvano najvjerojatnije je komemorirala (124) Gaja Masklinija Romula i Gerontijanu. Gerontiana je po svemu sudeći izvedenica kognomena Gerontius grčkoga podrijetla. ${ }^{279}$ Aurelije Delmacije postavio je urnu (125) ocu, veteranu Aureliju Apolinaru. Njihov je gentilicij potvrđen većinom u Dalmaciji, ali ga ima i u drugim provincijama. ${ }^{280}$ Veteran Maksimin postavio je nadgrobni natpis (126) sinu koji je živio 27 godina. Od sinova gentilicija sačuvano je [---]inius i mogućnosti restitucije su brojne. Od kognomena je sačuvano [---]timus, a od nekoliko mogućih rješenja najizglednije je Maritimus, ${ }^{281}$ kognomen potvrđen u Saloni na desetak natpisa iz vremena kasnog principata. ${ }^{282}$

\footnotetext{
270 ALFÖLDY 1969: 246, 247, OPEL III: 78, Messianus.

271 Za njihovu dataciju v. MATIJEVIĆ 2015a: 116-117.

272 CIL 3, 2118 iz Podstrane: $D$ (is) M(anibus) Caniae Ur/banae vilicae q/uae vixit ann(orum) LV ^ Cania Ursina fili/ae T(itus) Attius Verec/undianus gener matri incompa/rabili; v. MARŠIĆ 2014: 208-209.

273 ALFÖLDY 1969: 72, OPEL II: 31, Canius.

274 ALFÖLDY 1969: 317.

275 ALFÖLDY 1969: 83.

276 ALFÖLDY 1969: 169.

277 ALFÖLDY 1969: 253, OPEL III: 102, Nigrinus.

278 ALFÖLDY 1969: 169, OPEL II: 24-25, Callistus.

279 ALFÖLDY 1969: 211.

280 OPEL II: 92, Dalmatius.

281 FERJANČIĆ 2002: 276, br. 283.

282 ALFÖLDY 1969: 239.
} 


\section{1. Osobe s natpisa legionara neodredivog statusa (T. III.1., 127-133)}

Tri fragmentirana natpisa datiraju se nakon 42. godine. ${ }^{283}$ Ulomak natpisa (127) pripadnika Sedme legije sačuvao je dva kognomena (Respectus, Abascantus) za koje se ne može reći jesu li pripadali muškim ili ženskim osobama. Drugi je tipičan za oslobođenike pa bi se moglo raditi o osobi takvog statusa. ${ }^{284}$ Pripadnik Jedanaeste legije postavio je nadgrobni natpis (128) sebi i svojim oslobođenicima (et libertis suis). Iz istoga je vremena vrlo oštećen natpis (129) pripadnika Sedme ili Jedanaeste legije čiji status ne znamo. Postavio ga je sebi i svojima. ${ }^{285}$

Na nadgrobnom žrtveniku (130) Aurelija(?) Feroka iz Druge legije pomoćnice spominju se još četiri osobe čija su imena djelomično sačuvana. ${ }^{286}$ Gledajući predloženu restituciju ovih redaka jedino oko čega nema sumnje jest da je nadgrobni žrtvenik bio podignut Feroku i Metrodori koji su oslovljeni kao roditelji. Treća komemorirana osoba je Bazilid, po svemu sudeći ujak dvojice komemoratora koji su se najvjerojatnije zvali Terminal i Kvintilijan. Ako je tumačenje ispravno, Bazilid je morao biti i Metrodorin brat. U prilog ovakvoj njihovoj povezanosti ide i grčko podrijetlo njihovih kognomena. Terminal i Kvintilijan nosili su Ferokov gentilicij jer im je on, sudeći po sadržaju 8. i 9. retka, bio otac. ${ }^{287}$ Kognomen Terminalis nije poznat na natpisima iz provincije Dalmacije, ali jest u rimskome svijetu, posebno u Italiji. ${ }^{288}$ Kognomen Quintilianus u Saloni je potvrđen jednim natpisom iz doba kasnog principata, drugdje nema mnogo njegovih primjera. ${ }^{289}$ Kognomen Basilides grčkoga je podrijetla i u Saloni zabilježen tek jedanput iz vremena kasnog principata. ${ }^{290}$ Istoga je podrijetla i kognomen Metrodorus (-os), poznat s još po jednog natpisa iz Salone i Narone. U oba je primjera pripadao muškim osobama. ${ }^{291}$

Tri spomenika potječu iz razdoblja kasnog principata. ${ }^{292} \mathrm{Na}$ steli (131) beneficijarija Grata(?) spominje se i njegova supruga od čijeg je imena sačuvano [---]PONON[---]. Mogao bi to biti ženski oblik imena Bononius koje u Dalmaciji nije potvrđeno, ali je u drugim krajevima Carstva poznato i kao gentilicij i kao kognomen. ${ }^{293}$ Beneficijarij

\footnotetext{
MATIJEVIĆ 2015a: 227-228.

284 Usp. ALFÖLDY 1969: 140.

285 Za dataciju ovih ulomaka v. MATIJEVIĆ 2015a: 227-228.

286 O dataciji žrtvenika u kraj 2. ili početak 3. stoljeća i detaljnije o mogućnostima restitucije v. MATIJEVIĆ 2012a: 60-66.

287 MATIJEVIĆ 2012a: 63.

288 V. npr. $A E ́$ 1912, 113; AÉ 1984, 740; CIL 3, 14048; CIL 5, 2212; CIL 6, 15554; CIL 6, 22105 , također i OPEL IV: 113, Terminalis.

289 ALFÖLDY 1969: 279, OPEL IV: 18-19, Quintilianus.

290 ALFÖLDY 1969: 163, OPEL I: 113, Basilides.

291 ALFÖLDY 1969: 248, OPEL III: 80, Metrodorus.

292 MATIJEVIĆ 2015a: 148, 230, 234.
} 
[---]rius postavio je nadgrobni natpis (132) sebi i još trima osobama. U 4. retku je završni dio imena muške osobe [---]onianus. U Dalmaciji zasad nije potvrđen niti jedan gentilicij koji završava tako, a kognomena ima nekoliko: Aponianus, ${ }^{294}$ Batonianus, ${ }^{295}$ Varronianus, ${ }^{296} \mathrm{u}$ Saloni su potvrđeni Apollonianus ${ }^{297}$ i Obultronianus. ${ }^{298}$ Stoga je opravdano pretpostaviti da je njegov gentilicij, jednako kao i beneficijarijev, bio uklesan na lijevoj, većoj strani natpisa koja nedostaje. U 2. retku je sačuvan završni dio kognomena ženske osobe (Longina) kojoj je natpis podignut. ${ }^{299}$ Ostaje pitanje kako protumačiti sadržaj 1. retka ([---]egiae). Mogao bi to biti završni dio Longininog gentilicija ili kognomena još jedne ženske osobe, ali nije jasno kako su glasili. U Dalmaciji zasad nije potvrđen niti jedan sa završetkom na -egius, -egia. ${ }^{300}$ Na sarkofagu (133) Aurelija Flava(?) iz Prve italske legije spominju se dvije ženske osobe koje također nose gentilicij Aurelius. Zbog imenice parentes moglo bi se reći da je Aurelija postavila sarkofag roditeljima Aureliji i legionaru Aureliju Flavu(?).

\section{2. Osobe s natpisa augzilijara neodredivog statusa $\mathbf{i}$ natpisa neodredive postrojbe}

(T. III.2., 134-136)

Tri spomenika datiraju u doba kasnog principata. Pompeja Firmina komemorirala je (134) supruga koji je služio u Osmoj dobrovoljačkoj kohorti. Njezin gentilicij posvuda je rasprostranjen, a gotovo sve potvrde iz Dalmacije potječu iz Salone iz vremena kasnog principata. ${ }^{301}$ Supruga od čijeg je kognomena sačuvan završni dio [---]TVRA postavila je urnu (135) suprugu iz iste kohorte. Mogao bi to biti ostatak kognomena Maturus, ${ }^{302}$ iako u u obzir može doći i Profuturus, također potvrđen u Saloni. ${ }^{303}$ Vojnik [---]ije Lici[nije(?) ---] postavio je stelu (136) svojem djetetu koje je preminulo u dobi od 14 godina i još nekoj osobi čije nije sačuvano. ${ }^{304}$

\footnotetext{
293 OPEL I: 126, Bononius.

294 ALFÖLDY 1969: 153.

295 ALFÖLDY 1969: 164.

296 ALFÖLDY 1969: 322.

297 ALFÖLDY 1969: 153.

298 ALFÖLDY 1969: 255.

299 ALFÖLDY 1969: 232, OPEL III: 31, Longinus.

300 ALFÖLDY 1969: 33-333.

301 ALFÖLDY 1969: 111, OPEL III: 150-151, Pompeius.

302 ALFÖLDY 1969: 241.

303 ALFÖLDY 1969: 275-276.

304 CIL III 12901.
} 


\section{ZAKLJUČAK}

Obuhvaćeno je 136 salonitanskih vojničkih nadgrobnih natpisa iz doba principata koji uz ime aktivnog vojnika ili veterana spominju još jednu ili više osoba. Velika većina od čak 190 tih osoba bila je civilnog statusa, a tek nekoliko natpisa spominje još jednoga vojnika. Prvu skupinu čini 75 natpisa aktivnih vojnika (Tab. I), u drugoj skupini je 51 veteranski natpis (Tab. II), treća skupina (Tab. III) broji 10 natpisa koji su fragmentirani toliko da se ne može odrediti je li vojnik aktivan, ili veteran. U obzir su uzeti svi natpisi na kojima se sigurno spominje neka druga osoba, pa čak i fragmentirani, iako se na njima u velikom broju primjera ne može sigurno restituirati ime osobe, odrediti odnos s vojnikom i razlučiti tko je komemorator, a tko komemorirani.

Od aktivnih vojnika (Tab. I), 17 legionara (1-17) i sedmorica augzilijara (4147) živjeli su u doba ranoga principata. Upadljivo je da samo centurioni i niži časnici imaju žene $(8,13,44,45)$, najvjerojatnije još jedan centurion (12), ali i jedan iz nepoznate postrojbe (70) što može sugerirati da je na njegovom fragmentiranom natpisu bila spomenuta barem još jedna i to višerangirana služba. Ovo jasno govori da su zakonski priznate supruge (uxor, coniunx) imali i tako ih oslovljavali visokorangirani vojnici. Odnose sa ženama imali su nesumnjivo i ostali vojnici što se može nazrijeti kroz njihovo spominjanje hospita $(11,46)$ koje imaju građansko pravo, kao i oslobođenica $(2,3)$. Jednoga je beneficijarija (16) komemorirala majka, što se može objasniti time što je služio u rodnome Ekvu i njegovoj blizini. Trojicu preminulih legionara komemorirala su braća - za dva primjera bi se moglo reći da su krvni srodnici $(7,10)$, a za jedan (14) da su „braća po oružju“. Oslobođenike i oslobođenice imala su čak desetorica vojnika (2-4, $6,7,9,13,16,17,44)$. Često se može samo pretpostaviti koje je vrste bila veza između vojnika i osobe koja je spomenuta na njegovu natpisu. U četiri primjera mogao je to biti kolega iz postrojbe $(1,5,41,42)$. Prva trojica imala su građansko pravo, dakle isti status kao i vojnici kojima su spomenici postavljeni. To može značiti da su imali jednak rang kao i mogući kolege u postrojbi. Ime četvrtoga nije sačuvano, ali postoje indicije o peregrinskom imenovanju i višerangiranom statusu u ali. Na jednome natpisu (14) spomenuta je nevjesta, na dva $(7,17)$ možda oslobođenici, centurioni iz legije (15), na jednome (47) se karakter odnosa ne može naslutiti. U 20 primjera može se odrediti tko je koga komemorirao. Vojnici su komemoratori šest puta (30\%), a njih sedam puta (35\%) komemoriraju članovi obitelji (žena, brat, sestra, roditelji), pet puta (25\%) oslobođenici ili oslobođenice, s time da su od toga dvije komemoracije učinjene zajedno s vojnikovim bratom odnosno ženom. Jednoga vojnika komemorirala je hospita, a jednoga prijatelj kolega iz postrojbe.

Drugi dio skupine čine 51 aktivni vojnik iz kasnoga principata (Tab. 1) od čega su 23 legionara (18-40), 23 augzilijara i mornara (47-69) te šestorica vojnika za 
koje se ne zna pripadnost postrojbi (70-75). Žene i djeca potvrđeni su za 22 vojnika (43\%) $(18,20-22,24,25,31-33,35,37-39,54,56,62,64-67,69,74)$, roditelji su spomenuti na natpisima osmorice vojnika $(16 \%)(23,40,53,54,58,60,62,71) \mathrm{s}$ time da je u dva primjera roditelj spomenut zajedno sa ženom $(18,35)$ što jasno pokazuje da dominiraju odnosi vojnika i članova njihovih obitelji. Braća se spominju tek pet puta $(19,21,32,61,72)(10 \%)$, tri puta hospita $(46,50,60)$ i suborac iz legije $(29,30,36)$, dva puta sestra $(27,57)$, oslobođenik $(28,75)$, prijatelj $(27$, 61), jednom prijateljica (37), šurjakinja (37), punac (37), nećakinja (57), rob (52), oslobođenica (26). Tko je koga komemorirao moguće je utvrditi kod 50 natpisa. Članovi obitelji (žena, djeca, brat, sestra, roditelji) komemorirali su vojnike u 21 primjeru (42\%), 14 primjera (28\%) pokazuje da su vojnici komemorirali članove obitelji, po jedan puta su komemoratori bili kontubernal, rob, alumna i više puta osobe za koje je nemoguće odrediti karakter odnosa s vojnikom. Znakoviti su nadgrobni natpisi vojnika iz Prve italske legije (29-32) i Četrnaeste dvojne legije (35, 36) čije su veksilacije boravile u Saloni tijekom severskog doba, odnosno kasnog principata. U ranoseversko doba vojnika Aurelija Mukatru komemorirao je njegov suborac iz legije Aurelije Sabazijan (29), obojica tračkog ili orijentalnog podrijetla. Desetljeće-dva kasnije vojnika ove veksilacije komemorirao je također suborac iz postrojbe (30). Podatak o međusobnom komemoriranju, u barem dva navrata, jasno govori da su vojnici iz ove veksilacije bili svojevrsna zatvorena skupina koja nije ostvarila dovoljno snažne odnose s lokalnim stanovništvom pa su brigu o njihovom ukopu preuzeli suborci iz postrojbe. Međutim, i to se promijenilo jer je vojnika Aurelija Poncijana (31) iz kasnoseverskog doba komemorirao sin Aurelije Kvintijan što govori da je on očito imao vlastitu obitelj. Vojnika Aurelija Marcijala, njegovu ženu i sina komemorirao je brat Disdozi čije ime izričito upućuje na tračko podrijetlo, što posredno može govoriti i da je Marcijal bio istoga podrijetla i navesti na pretpostavku da je obitelj osnovao u novoj sredini. Međutim, nije isključeno ni da je njegova obitelj s njime došla ovamo. Donekle je slično i s pripadnicima veksilacije Četrnaeste dvojne legije. Naime, Avicija Augurina komemorira suborac iz legije Ulpije Kalija koji je vjerojatno stranac u Saloni jer nema drugih potvrda njegova kognomena u provinciji. Atrekcija Cezijana komemorira majka Atrekcija koja je najvjerojatnije podrijetlom iz noričkih predjela ili Narbonske Galije, a kako ovaj gentilicij nije potvrđen u provinciji vrlo je izgledno da je bila strankinja. Prema tome se smije zaključiti da je zajedno s nevjestom, drugom komemoratoricom na Cesijanovoj steli, boravila u Saloni, mjestu gdje je sin služio vojsku. Međutim, unatoč tome što u Dalmaciji zasad nema drugih potvrda njezina gentilicija, kako je spomenik postavio jedan roditelj, nije isključeno ni lokalno podrijetlo ove obitelji. Puno je veća vjerojatnost da su lokalnog podrijetla bile žene vojnika $(54,56,62,64$, $65,69)$ koji su služili u kohortama i u mornaričkom odjeljenju u provinciji. Kako protumačiti obiteljske veze zabilježene na deset natpisa namjesnikovih oficijala (18-27) čije su legije bile stalno stacionirane u logorima na Dunavu, u panonskim 
i mezijskim provincijama? Poslani su odande kako bi služili u namjesnikovu uredu u Saloni ili u unutrašnjosti Dalmacije. U čak devet primjera komemorirale su ih žene, majke, brat odnosno sestra, a jedan od njih komemorira dijete. Smije li se pretpostaviti da su žene i djeca došli s njima, ili su ove veze nastale nakon njihova dolaska u provinciju? Karakteristike imena njihovih žena ne odskaču od imena svojstvenih provinciji Dalmaciji, te nema osnove pretpostavljati da su ovdje bile strankinje. Također, nije isključeno ni da su njihovi supruzi bili zavičajem Dalmatinci, a da su se u podunavske legije prijavili znajući da jednoga dana mogu biti poslani na službu u rodni kraj.

Teško je odrediti podrijetlo osoba s kojima su vojnici na različite načine bili povezani. Žene vojnika iz ranoga principata imale su građansko pravo i nosile gentilicije italskog podrijetla (Iulius, Apuleius, Bennius, Calpurnius, Cordius), a jednako vrijedi i za hospite (Papirius, Iulius). Najvjerojatnije su bile iz Dalmacije, odnosno, potjecale su iz sredine za koju su njihovi muževi bili vezani vojnom službom. O mogućim kolegama iz postrojbe također se malo može reći. Primjerice, Lucije Gelije pripadao je istaknutoj salonitanskoj familiji jer su ostali nositelji ovoga gentilicija u gradu bili imućni i utjecajni, dok se za Gaja Avinija Postumija s priličnom sigurnošću može reći da je bio Italik jer je to do sada u Dalmaciji jedina potvrda njegova, ionako rijetkoga, gentilicija. Štoviše, velika većina pripadnika Sedme legije u Dalmaciji u ono vrijeme stranoga je podrijetla. Gotovo je nemoguće odrediti podrijetlo legionarovog brata Marka Eupunija Viktora i nevjeste Ekvitine Tercije jer su ovo zasada jedine potvrde njihovih gentilicija u Dalmaciji, pa i u čitavom europskom dijelu Carstva. Slično je i s augzilijarima. Samo je u jednom primjeru moguće utvrditi da je prijatelj komemorirao prijatelja, vjerojatno iz iste postrojbe, i da su bili peregrinskog statusa i podrijetlom iz jugoistočnih dijelova Dalmacije. U kasnome principatu gotovo je nemoguće izdvojiti ime neke druge osobe povezane s vojnikom, a da se za nju smije izričito kazati da je bila stranac. Svi njihovi gentiliciji i kognomeni već su potvrđeni u Saloni i Dalmaciji, pa čak i oni koji nisu (kao npr. gentilicij Atrectius) opet ne moraju pripadati strancima.

U veteranskoj skupini 20 legionara (T. II, 76.-95), petorica augzilijara te mornara $(102-105,112)$ su iz razdoblja ranoga principata. C̆ak 14 legionara je imalo obitelji što jasno dokazuju spominjući supruge i potomke $(77-81,83,85,86,88$, $89,91,93-95)$. Sve supruge, posve je očekivano, imaju građansko pravo i nose gentilicije italskog podrijetla već potvrđene u Saloni (Hostilius, Marius, Pasius, Petilius). Ipak, za pojedine bi se moglo pretpostaviti da su bile strankinje poput Nerije Pijeris (89) čiji italski gentilicij uopće nije potvrđen u Dalmaciji. Veterani za razliku od aktivnih vojnika uopće nisu spominjali hospite, a i oslobođenice su imala petorica od kojih se za tri može pretpostaviti da su bile njihove žene (76, $82,84)$. Preostala dvojica s oslobođenicama $(85,93)$ vjerojatno nisu bila u takvoj vrsti veze. Iz ovoga je vremena vrlo mali broj augzilijara i mornara na čijim su natpisima spomenute ostale osobe. Dvojica su imala oslobođenike $(102,105)$. 
Vojničkom diplomom jednoga pješaka zajamčen je civitet njegovoj ženi Madeni, kćeri Plarenta iz dalmatinskog naroda Deramista, i njihovome djetetu, sinu Gaju (104). To znači da je pješak razvio vezu s osobom peregrinskog statusa i da su očito bili dovoljno romanizirani jer su sinu dali jedno od najuobičajenijih rimskih imena. Misicij Nove klaudijevske ale postavio je stelu sestri Pami (103) čije je ime tipično za Biturige u Galiji Akvitaniji odakle je i on potjecao. Čini se da ovo navodi na zaključak kako je bila s bratom tijekom njegove vojne službe u Dalmaciji. Odnose komemorator-komemorirani moguće je ustanoviti kod 19 legijskih veterana koji u devet primjera postavljaju nadgrobne spomenike (47\%), a u osam primjera (42\%) komemoriraju ih članovi obitelji, zatim dvaput njihovi oslobođenici (10\%). Ove je odnose moguće ustanoviti u svega trojice bivših augzilijara.

U drugom dijelu skupine veteranskih natpisa su šestorica legionara (96-101), te 20 augzilijara, mornara i bivših pripadnika nepoznatih postrojbi (106-111, 113-126) iz kasnoga principata. Potpuno suprotan brojčani omjer legijskih i augzilijarnih natpisa iz radoblja kansog principata rezultat je izostanka legionara iz Salone i pojačane prisutnosti augzilijara i mornara. Legijski veterani osnovali su obitelji sa ženama koje imaju građansko pravo preneseno i na njihovu djecu. Njihovi gentiliciji potvrđeni su u rimskom svijetu (Caelius, Titius, Marcius, Valerius, Venerius). Isto vrijedi i za augzilijarne i mornaričke veterane čije žene u gotovo svim primjerima imaju građansko pravo te nose već poznate gentilicije (Novellius, Iulius, Flavius, Sempronius, Papirius, Octavius, Canius, Bennius(?), Claudius, Aurelius). Jedina iznimka je Antistija, kći Anterotova, (109) jer ima peregrinsko imenovanje. Rijetko se spominju oslobođenici, u dva primjera pojedinačno (117, 118), a u trećem (106) preko sintagme koja ih podrazumijeva veći broj. Njihovi kognomeni tipični su za oslobođeničku populaciju (Urbanus, Philocyrius, Chrysanthus). Tko je koga komemorirao može se ustanoviti za šestoricu legijskih veterana. Jedan je za života zajedno sa ženom postavio nadgrobni spomenik, drugi je komemorirao ženu i sina, treći sina, a triput su članovi obitelji komemorirali legijske veterane. Na svim natpisima veterana iz kasnoga principata samo je nekoliko osoba imalo s njima drukčiju vezu (prijatelj, kontubernal, rob(?)). Triput se veza ne može odrediti, ali bi se prema istovjetnosti gentilicija moglo pretpostaviti da se radilo o veteranovom sinu ili oslobođeniku. Triput je upisan izraz koji podrazumijeva članova šire obitelji.

$\mathrm{Na}$ deset vrlo oštećenih natpisa legionara i augzilijara ne može se odrediti jesu li, kad je spomenik postavljen, bili aktivni ili veterani. Imena osoba koje su povezane s njima ne mogu se potpuno restituirati, a ne može se uvijek odrediti ni narav njihovih odnosa. Ipak, može se zaključiti da su ženu i djecu imala trojica legionara $(130,131,133)$, dvojica augzilijara $(134,135)$ i jedan vojnik (136).

Podatak o vojnikovom ili vetranovom nasljedniku postoji u ukupno 11 primjera. Nasljednici se uz aktivne vojnike $(3,13,15,32,34,36,75)$ pojavljuju daleko više nego uz veterane $(102,105,108,117)$. Oslobođenici su nasljednici u pet primjera 
(45\%) i najvjerojatnije još jedanput, po jedanput su nasljednici brat, kolega iz legije i djeca, te najvjerojatnije kolege iz postrojbe i jedna osoba u nepoznatoj vezi s vojnikom.

Vojnici su samostalno ili sa ženama u sedam primjera komemorirali vlastitu djecu $(22,25,33,57,67,70,74)$, dok su veterani to učinili samo četiri puta (85, $93,101,126)$. Jedanput je vojnik nepoznatog statusa (136) komemorirao svoje dijete. Starosna dob djece u trenutku smrti bila je vrlo niska - najmlađe preminulo dijete imalo je dvije godine i devet mjeseci, a najstarije 25 godina. Prosjek njihovih godina u trenutku smrti je 10,69 godina.

\section{BIBLIOGRAFIJA}

\section{Kratice}

$A E$ - L'année épigraphique: revue des publications epigraphiques relatives a l'antiquite romaine / fondee en 1888. par Rene Cagnat; Mireille Corbier directeur. Paris: Presses Universitaires de France 1889.-

CBFIR - Corpus der griechischen und lateinischen Beneficiarier-Inschriften des Römischen

Reiches, Forschungen und Berichte zur Vor- und Frühgeschichte in Baden-Württemberg, 40.; Römische Weihebezirk von Osterburken / Landesdenkmalamt Baden-Württemberg, 1.

Stuttgart.

CIL - Corpus Inscriptionum Latinarum, Berlin 1863.-

EDH - Epigraphische Datenbank Heidelberg (https://edh-www.adw.uni-heidelberg.de/ home) (28. 5. 2019)

Eph. Ep. - Ephemeris Epigraphica. Deutsches Archäologisches Institut. Abteilung (Roma); Instituto di corrispondenza archeologica (Roma) Romae : Institutus archaeologicus Romanus; Berolini: G. Reimer, 1872-1913

ILIug - Anna et Jaro Šašel, Inscriptiones latinae quae in Iugoslavia inter annos MCMXL et MCMLX repertae et editae sunt (Situla, 5, Ljubljana, 1963); Inscriptiones latinae quae in Iugoslavia inter annos MCMLX et MCMLXX repertae et editae sunt (Situla, 19, Ljubljana, 1978); Inscriptiones latinae quae in Iugoslavia inter annos MCMII et MCMXL repertae et editae sunt (Situla, 25, Ljubljana, 1986).

ILS - Dessau, Hermann. Inscriptiones Latinae Selectae. Berlin 1892.-1916.

OPEL I-Onomasticon provinciarum Europae latinarum, vol. I: Aba-Bysanus, ex materia ab András Mócsy, Reinhardo Feldmann, Elisabetha Marton et Mária Szilágyi collecta, composuit et correxit Barnabás Lőrincz, Budapest, 2005.

OPEL II - Onomasticon provinciarum Europae latinarum, vol. II: Cabalicius-Ixus, ex materia ab András Mócsy, Reinhardo Feldmann, Elisabetha Marton et Mária Szilágyi collecta, composuit et correxit Barnabás Lőrincz, Wien, 1999. 
OPEL III - Onomasticon provinciarum Europae latinarum, vol. III: Labareus-Pythea, ex materia ab András Mócsy, Reinhardo Feldmann, Elisabetha Marton et Mária Szilágyi collecta, composuit et correxit Barnabás Lőrincz, Wien, 2000.

OPEL IV - Onomasticon provinciarum Europae latinarum, vol. IV: Qvadratia-Zvres, ex materia ab András Mócsy, Reinhardo Feldmann, Elisabetha Marton et Mária Szilágyi collecta, composuit et correxit Barnabás Lörincz, Wien, 2002.

PWRE - Paulys Real-Encyklopädie der classischen Altertumswissenschaft, Stuttgart.

\section{Literatura}

ALFÖLDY, Géza. 1969. Die Personennamen in der römischen Provinz Dalmatia, Heidelberg: Carl Winter, 1969.

ALFÖLDY, Géza. 1987. Die auxiliartruppen der Provinz Dalmatien, U Römische Heeresgeschichte. Beiträge 1962-1985. (MAVORS: Roman Army Researches III), ur. Michael. P. Speidel, 239-297. Amsterdam: J.C. Gieben.

ALLISON, Penelope. 2011. Soldiers' Families in the Early Roman Empire, U A Companion to Families in the Greek and Roman Worlds, ur. Beryl Rawson, Wiley-Blackwell, 161-183.

BETZ, Artur. 1938. Untersuchungen zur militargeschichte der romischen Provinz Dalmatien, Abhandlungen des archaologisch-epigrafischen Seminars der Universitat Wien, Neue Folge, Heft 3. Wien.

BOJANOVSKI, Ivo. 1988. Bosna i Hercegovina u antičko doba, Akademija nauka i umjetnosti Bosne i Hercegovine, Djela, knjiga 66, Centar za balkanološka isipitivanja, knjiga 6, 1988.

BULIĆ, Frane. 1885. Iscrizioni inedite, Bullettino di archeologia e storia dalmata 8: 66-73.

BULIĆ, Frane. 1886. Iscrizioni inedite, Bullettino di archeologia e storia dalmata 9: 8-10.

BULIĆ, Frane. 1887. Iscrizioni inedite, Bullettino di archeologia e storia dalmata 10: 57-59.

BULIĆ, Frane. 1904. Iscrizioni inedite, Bullettino di archeologia e storia dalmata 27: 41-55.

BUSH, Archie C. 1973. Consobrinus and Cousin, The Classical Journal 68: 161-165.

CAGNAT, René. 1914. Cours d'épigraphie latine, Paris.

CAMBI, Nenad. 1960 (1967). Personifikacije godišnjih doba na spomenicima Salone, Vjesnik za arheologiju i historiju dalmatinsku 62: 55-78.

CAMBI, Nenad. 2000. Imago Animi. Split.

CAMBI, Nenad. 2005. Kiparstvo rimske Dalmacije. Split.

CAMBI, Nenad. 2010. Sarkofazi lokalne produkcije u rimskoj Dalmaciji. Split.

CAMBI, Nenad i RAPANIĆ, Željko. 1979. Ara Lucija Granija Proklina, Vjesnik za arheologiju i historiju dalmatinsku 72-73: 93-107.

CAMPBELL, Brian. 1978. The Marriage of Soldiers under the Empire, Jorunal of Roman Studies 68: 153-166. 
CARROLL, Maureen. 2009. Dead soldiers on the move. Transporting bodies and commemorating men at home and abroad. ULIMES XX. XX conreso internacional de estudios sobre la frontera romana (Leon, Septiembre, 2006), ur. Angel Morillo, Norbert Hanel, Esperanza Martin, Madrid: Consejo Superior de Investigaciones Cientificas, 2009, 823-832.

COSME, Pierre i FAURE, Patrice. 2004. Identité militaire et avancement au centurionat dans les castra peregrina, Cahiers du Centre Gustave Glotz: 15, Paris, 343-356.

CUFF, David B. 2000. - The auxilia in Roman Britain and the Two Germanies from Augustus to Caracalla: Family, Religion and ,Romanization“, doktorska radnja (rukopis), Department of Classics, University of Toronto, Toronto, 2010., https://tspace.library. utoronto.ca/handle/1807/24732 (24. rujna 2014.)

DEMICHELI, Dino. 2012. Salonitani extra fines Dalmatiae (I). Svjedoci podrijetlom iz Salone na vojničkim diplomama, Tusculum 5: 47-57.

DEMICHELI, Dino. 2013. Salonitani extra fines Dalmatiae (II). Salonitanci u pretorijanskoj vojsci, Tusculum 6: 79-91.

DEMICHELI, Dino. 2015. Salonitani extra fines Dalmatiae (IV). Salonitanci u vojnoj službi (dio prvi), Tusculum 8: 59-77.

DEMICHELI, Dino. 2016. Nadgrobni natpis iz Klapavica sa spomenom centuriona kohorte VIII Voluntariorum Gaja Alazinija Valentina, Diadora 30: 109-122.

FAURE, Patrice. 2010. De Rome à Salone: T. Flavius Lucilius, cavalier de la garde impériale, Zeitschrift für Papyrologie und Epigraphik 172: 223-238.

FELLMANN, Rudolf. 2000. Die 11. Legion Claudia Pia Fidelis, U Les légions de Rome sous le Haut-Empire (Actes du Congrès de Lyon 17-19 septembre 1998), ur. Yann Le Bohec, Catherine Wolff, Lyon, 127-131.

FERJANČIĆ, Snežana. 2002. Naseljavanje legijskih veterana u balkanskim provincijama, I-III vek n. e., Srpska akademija nauka i umetnosti, Balkanološki institut, posebna izdanja 79, Beograd.

GABRIČEVIĆ, Branimir. 2015. Dva priloga poznavanju urbanističkog razvoja antičke Salone, 217-224, U Izbor iz djela, ur. Nenad Cambi, Književni krug Split.

GARNSEY, Peter. 1970. Septimius Severus nad the Marriage of Soldiers, California Studies in Classical Antiquity 3: 45-53.

GLAVIČIĆ, Miroslav. 2002. Gradski dužnosnici na natpisima obalnog područja rimske provincije Dalmacije, doktorska disertacija (rukopis), Filozofski fakultet u Zadru, Zadar.

HOLTHEIDE, Bernard. 1980. Matrona stolata - femina stolata, Zeitschrift für Papyrologie und Epigraphik 38: 1980, 127-134.

DEL HOYO, Javier. 2000. Agatemeris, nuevo antroponimo griego atestiguado en Hispania, Gerion 18: 315-321.

HULA, Edward. 1890. Epigraphisches aus Spalato, Archaeologisch epigraphische mittheilungen aus Oesterreich-Ungarn 13: 94-104.

JONES, Brian W. 1974. The Status of Dalmatia under Domitian, Classical Philology 69: 48-50. 
KURILIĆ, Anamarija. 2006. Recent epigraphic finds from the Roman province of Dalmatia, U Dalmatia. Research in the Roman Province 1970-2001. Papers in honour of J. J. Wilkes, ur. D. Davison, V. Gaffney, E. Marin, British Archaeological Reports, International Series 1576, Oxford, 133-147.

KURILIĆ, Anamarija. 2008. Ususret Liburnima. Studije o društvenoj povijesti ranorimske Liburnije, Zadar.

KURILIĆ, Anamarija. 2008 (2009). Imenovanje žena u ranorimskoj Liburniji, Archaeologia Adriatica 2: 161-167.

LASSÈRE, Jean-Marie. 2005. Manuel d'epigraphie romaine, Paris.

LE BOHEC, Yann i WOLFF, Catherine. 2000. Legiones Moesiae Superioris, U Les légions de Rome sous le Haut-Empire (Actes du Congrès de Lyon 17-19 septembre 1998), ur. Yann Le Bohec, Catherine Wolff, Lyon, 239-245.

LENDON, Jon E. 2006. Contubernalis, Commanipularis, and Commilito in Roman Soldiers' Epigraphy: Drawing the Distinction, Zeitschrift für Papyrologie und Epigraphik 157: 270-276.

MACMULLEN, Ramsay. 1984. The Legion as a Society, Historia 33: 440-456.

MARŠIĆ, Dražen. 2010. Izgubljeni salonitanski spomenici (II.) / Portretne stele vojnika VII. legije C. p. f. Gaja Lukrecija i Lucija Cezija Basa, Vjesnik za arheologiju i povijest dalmatinsku 103: 68-80.

MARŠIĆ, Dražen. 2014. Antički profil Podstrane i okolice, U Lucije Artorije Kast i legenda o kralju Arturu. Zbornik radova s međunarodnog znanstvenog skupa održanog u Podstrani 30. ožujka do 2. travnja 2012, ur. Nenad Cambi, John Matthews, Split, 187-230.

MARŠIĆ, Dražen. 2010. Salonitanska portretna stela Virdomara i Pame, Tusculum 8: 7-24. MATIJAŠIĆ, Robert. 2002. Uvod u latinsku epigrafiju, Filozofski fakultet Pula, Pula.

MATIJEVIĆ, Ivan. 2009. Dva neobjavljena natpisa Druge kohorte Kiresta iz Dalmacije, Diadora 23: 35-44.

MATIJEVIĆ, Ivan. 2011. Natpisi Prve kohorte Belgâ iz Salone, Vjesnik za arheologiju i povijest dalmatinsku 104: 181-207.

MATIJEVIĆ, Ivan. 2012a. Epigrafska potvrda pripadnika Legije druge pomoćnice (legio II Adiutrix) u Saloni, Tusculum 5: 59-70.

MATIJEVIĆ, Ivan. 2012b. O salonitanskim natpisima konzularnih beneficijarija iz legije Desete gemine (legio X Gemina), Vjesnik za arheologiju i povijest dalmatinsku 105: 67-82.

MATIJEVIĆ, Ivan. 2015a. Rimski vojnici na natpisima iz Salone iz doba principata, doktorska disertacija (rukopis), Zadar.

MATIJEVIĆ, Ivan. 2015b. Rimski vojnici i njihovi oslobođenici na natpisima iz Salone iz doba principata, Vjesnik za arheologiju i historiju dalmatinsku 108: 131-156

MATIJEVIĆ, Ivan. 2016. Singulari dalmatinskog namjesnika, Vjesnik za arheologiju $i$ historiju dalmatinsku 109: 193-224.

MATIJEVIĆ, Ivan. 2017a. O vojnoj karijeri centuriona Lucija Varija [---] po natpisu ILIug 2098 iz Salone, Tusculum 10: 199-210. 
MATIJEVIĆ, Ivan. 2017b - I. Matijević, Neobjavljena stela veterana legije Sedma Claudia pia fidelis iz Sikula, Miscellanea Hadriatica et Mediterranea 3: 125-138.

MATIJEVIĆ, Ivan. 2020 - Salonitanski natpisi vojnika i veterana na upravnim i vjerskim službama u nekim gradovima rimske Dalmacije (u tisku).

MEDINI, Julijan. 1985. Cognationes Salonitanae, Godišnjak Akademija nauka i umjetnosti Bosne i Hercegovine 23, Centar za balkanološka isipitivanja 21: 5-45.

MIHĂILESCU-BÎRLIBA, Lucrețiu. 2006. Les affranchis dans les provinces romaines de l'Illyricum, Wiesbaden.

OLSON, Kelly. 2008. Dress and the Roman Woman: Self-Presentation and Society, Routledge.

PHANG, Sara E. 2001. The Marriage of Roman Soldiers (13 BC-AD 235): Law and Family in the Imperial Army, Boston.

PITILLAS SALAÑER, Eduardo. 2006. Soldados auxiliares del ejèrcito romano originarios del NW de Hispania (s. I d.C.), Hispania antiqua 30: 21-34.

RANKOV, Boris. 1990. Frumentarii, the Castra peregrina and the provincial officia, Zeitschrift für Papyrologie und Epigraphik 80: 176-182.

RITTERLING, Emil. 1925. Legio, PWRE 12: 1211-1829.

ROSS TAYLOR, Lily. 1961. Freedmen and Freeborn in the Epitaphs of Imperial Rome, The American Journal of Philology 82: 113-132.

SALLER, Richard P. 1984. „Familia, Domus“, and the Roman Conception of the Family, Phoenix 38: 336-355.

SALLER, Richard P. i SHAW, Brent D. 1984. Tombstones nad Roman family Relations in the Principate: Civilians, Soldiers and Slaves, Journal of Roman Studies 74: 124-156.

SALWAY, Benet. 1994. What's in a Name? A Survey of Roman Onomastic Practice from c. 700 B.C. to A.D. 700, Journal of Roman Studies 84: 124-145.

SCHEIDEL, Walter. 2007. Marriage, Families, and Survival: Demographic Aspects, U A Companion to the Roman Army, ur. Paul Erdkamp, 417-434, Blackwell Publishing.

SOLIN,Heikki. 2003. Die griechischen Personennamen in Rom. Ein Namenbuch. Zweite, vollig neu bearbeitete Auflage, erster band, Berlin - New York: Walter de Gruyter.

Southern, Pat. 2006. The Roman army, Santa Barbara, 2006.

SPAUL, John E. H. 1995. Ala I Pannoniorum - one or many?, Zeitschrift für Papyrologie und Epigraphik 105: 63-73.

SPEIDEL, Michael P. 1978. Guards of the Roman armies: an essay on the singulares of the provinces, Bonn, 1978.

SPEIDEL, Michael P. 1989. The soldiers' servants, Ancient Society 20: 239-245.

STICOTTI, Piero. 1893. Bericht über einen Ausflug nach Liburnien und Dalmatien 1890 und 1891, Archaeologisch epigraphische mittheilungen aus Oesterreich-Ungarn 16: 141-155.

RAWSON, Beryl. 2005. Children and Childhood in Roman Italy, Oxford University Press.

SANDYS, John E. 1919. Latin epigraphy. An introduction to the Study of Latin Inscriptions, New York. 
TEMIN, Peter. 2004. The Labor Market of the Early Roman Empire, The Journal of Interdisciplinary History 34: 513-538.

TONČINIĆ, Domagoj. 2011. Spomenici VII. legije na području rimske provincije Dalmacije, Split.

TREGGIARI, Susan. 1981. „Contubernales“ in „Cil“" 6, Phoenix 35: 42-69.

TUDOR, D. 1971. Alföldy (Géza). Die Personennamen in der römischen Provinz Dalmatia, Revue belge de philologie et d'histoire 49: 86-90.

VISHNIA, Rachel F. Vishnia. 2002. The shadow Army: The Lixae and the Roman Legions, Zeitschrift für Papyrologie und Epigraphik 139: 265-272.

WEAVER, Paul R. C. 1972. Familia Caesaris: A Social Study of the Emperor's Freedmen and Slaves, Cambridge University Press.

BURKERT, Walter. 1979. Structure and History in Greek Mythology and Ritual, Berkeley,

Los Angeles, London: University of California Press.

WESCH-KLEIN, Gabriele. 2007. Recruits and Veterans. U A Companion to the Roman Army, ur. Paul Erdkamp, 435-450, Blackwell Publishing.

WESTERMANN, William L. 1955. The Slave Systems of Greek and Roman Antiquity, Philadelphia.

WILKES, John J. 1969. Dalmatia, London.

WILKES, John J. 1970. Equestrian Rank in Dalmatia under the Principate, U Adriatica praehistorica et antiqua. Miscellanea Gregorio Novak dicata, ur. Vladimir Mirosavljević, Duje Rendić-Miočević, Mate Suić, 529-551. Zagreb : Sveučilište, Arheološki institut Filozofskog fakulteta.

WILKES, John J. 2000. Army and Society in Roman Dalmatia, U Kaiser, Heer und Gesellschaft in der römischen Kaiserzeit, ur. G. Alföldy, B. Dobson, W. Eck, Stuttgart, 327-343. 


\section{Prilozi}

\begin{tabular}{|c|c|c|c|c|c|c|c|c|}
\hline 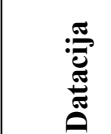 & 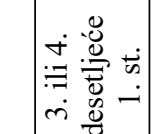 & \multicolumn{2}{|c|}{ : } & \multicolumn{4}{|c|}{ 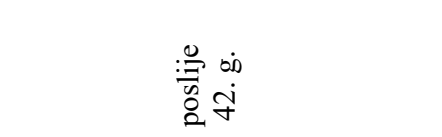 } & \multirow[t]{2}{*}{ 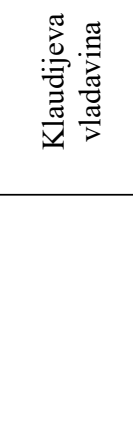 } \\
\hline 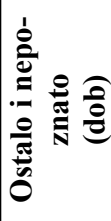 & 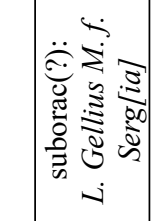 & & 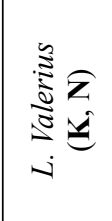 & & 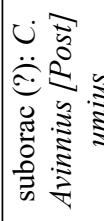 & & 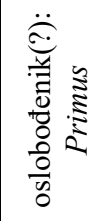 & \\
\hline 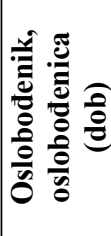 & & 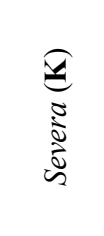 & 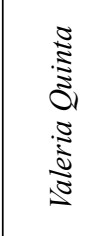 & 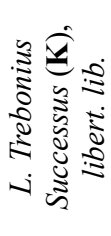 & & 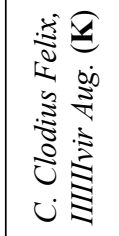 & 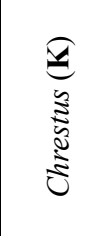 & \\
\hline 於 & 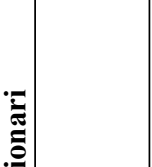 & & & & & & & \\
\hline 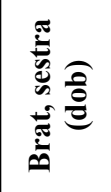 & |ذ: & & & 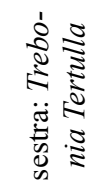 & & & 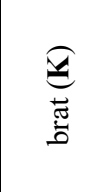 & \\
\hline 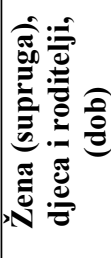 & & & & 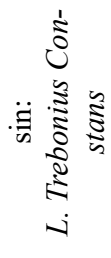 & & & & 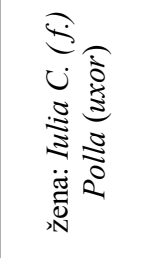 \\
\hline 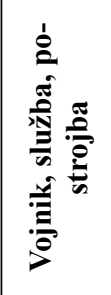 & 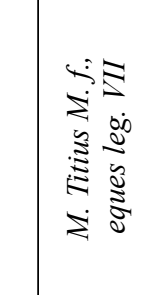 & 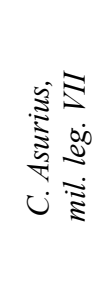 & 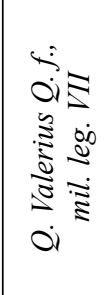 & 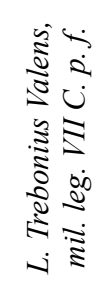 & 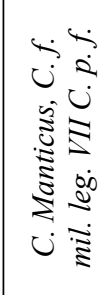 & 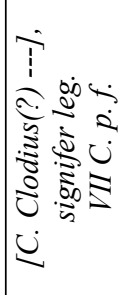 & 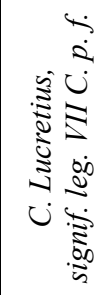 & 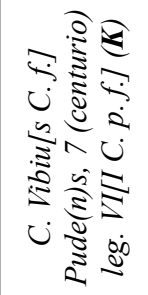 \\
\hline تُ & 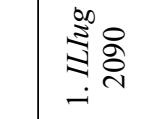 & 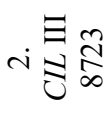 & ri & $+\underset{\infty}{\exists}$ & $\begin{array}{l}\stackrel{s}{\Xi} \tilde{\Xi} \\
\text { in } \\
\text { iे }\end{array}$ & 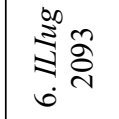 & 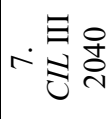 & 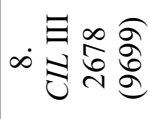 \\
\hline
\end{tabular}




\begin{tabular}{|c|c|c|c|c|c|c|c|c|}
\hline \multicolumn{2}{|c|}{ 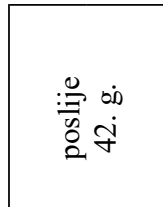 } & \multicolumn{2}{|r|}{ 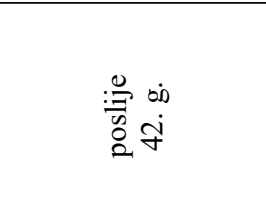 } & \multirow[t]{2}{*}{ 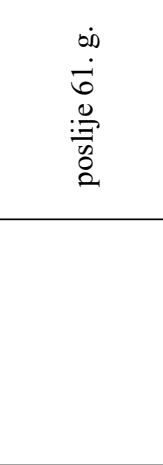 } & \multirow{2}{*}{ 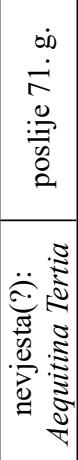 } & \multirow{2}{*}{ 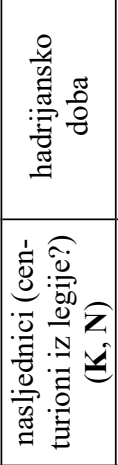 } & \multirow[t]{2}{*}{ 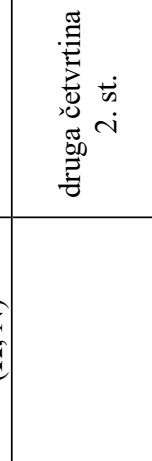 } & \multirow{2}{*}{ 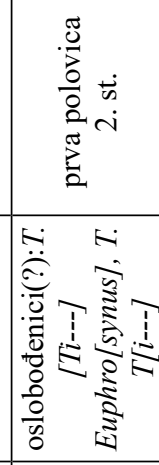 } \\
\hline & & & & & & & & \\
\hline 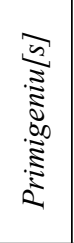 & & & & 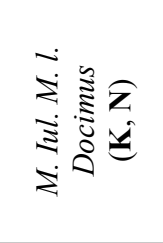 & & & 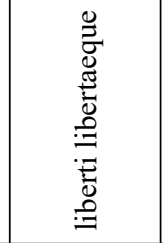 & 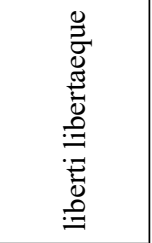 \\
\hline & & 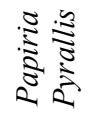 & & & & & & \\
\hline & 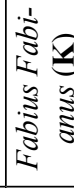 & & & & 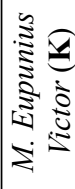 & & & \\
\hline & & & 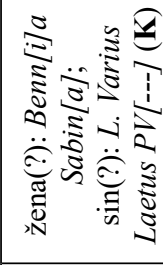 & 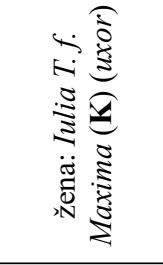 & & & 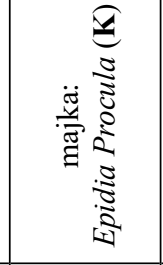 & \\
\hline 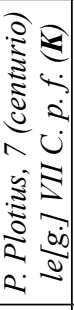 & 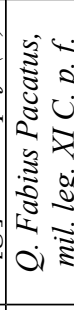 & 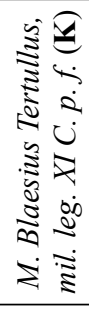 & 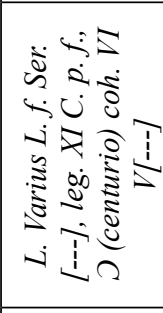 & 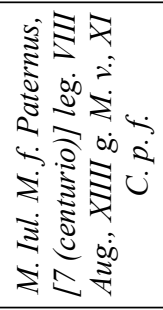 & 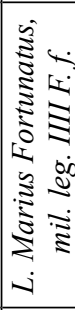 & 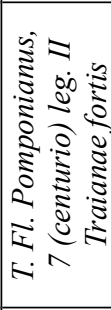 & 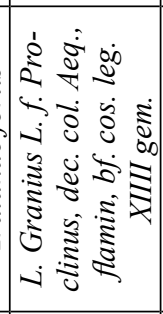 & 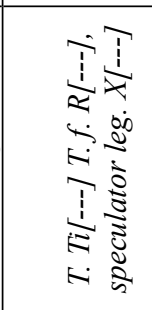 \\
\hline 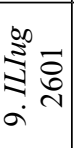 & 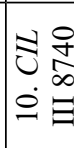 & 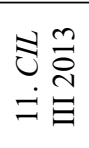 & 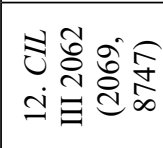 & 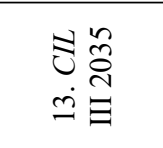 & 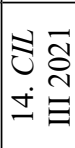 & $\begin{array}{l}\text { 퀑 } \\
\text { ஸे }\end{array}$ & 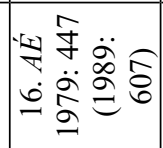 & 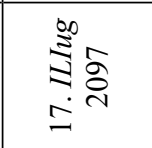 \\
\hline
\end{tabular}




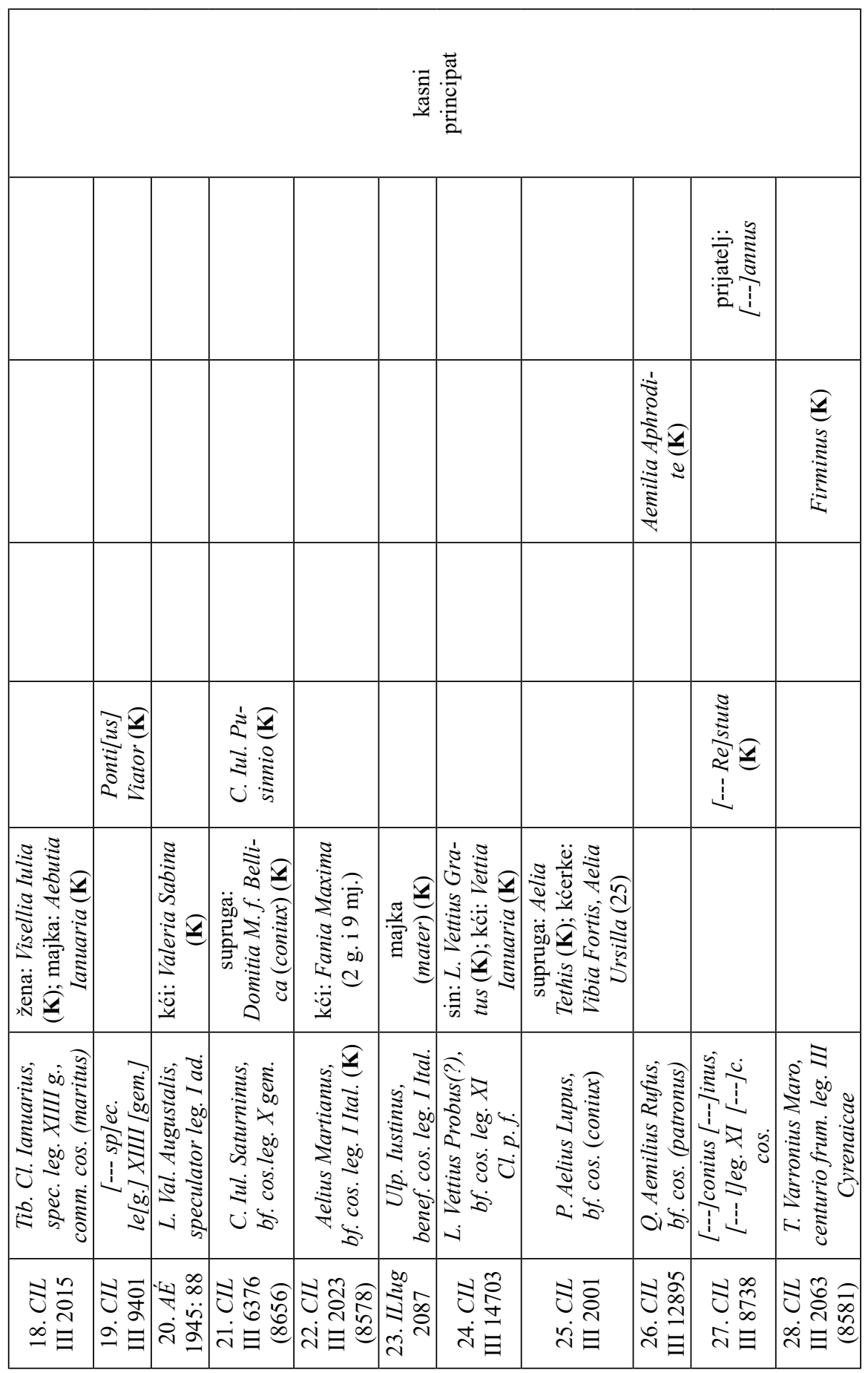




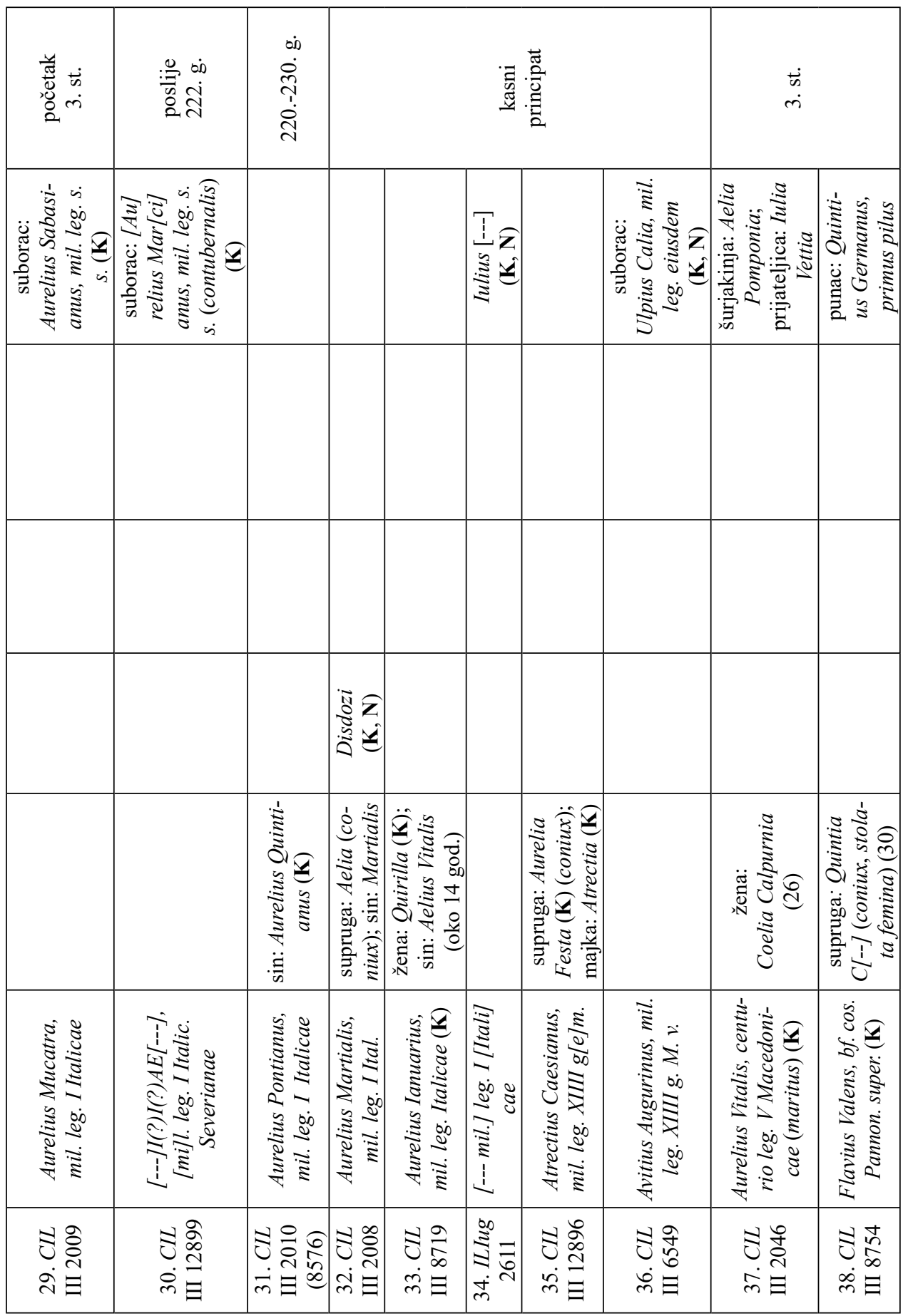




\begin{tabular}{|c|c|c|c|c|c|c|c|c|c|c|}
\hline \multirow[t]{4}{*}{$\begin{array}{l}\dot{\omega} \\
\dot{r} \\
\dot{c}\end{array}$} & \multirow[t]{2}{*}{$\begin{array}{l}\dot{\omega} \\
\dot{p}\end{array}$} & \multirow{2}{*}{ 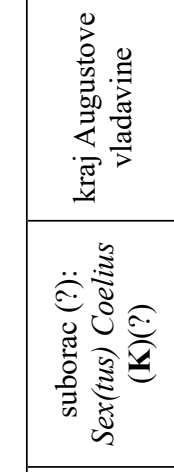 } & \multirow{2}{*}{ 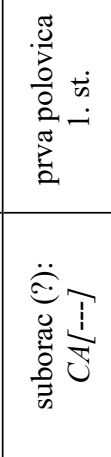 } & \multirow{2}{*}{ 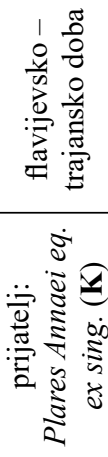 } & \multirow[t]{2}{*}{$\begin{array}{l}\dot{0} \\
\dot{0} \\
\dot{m} \\
\dot{0} \\
\dot{\beth}\end{array}$} & \multicolumn{2}{|c|}{ 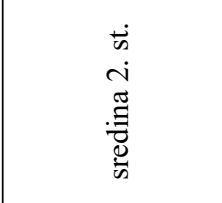 } & \multirow{2}{*}{ 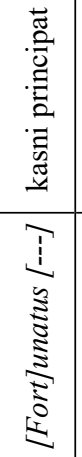 } & \multicolumn{2}{|c|}{ 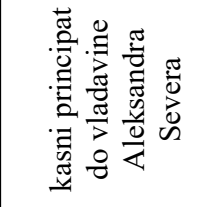 } \\
\hline & & & & & & & & & 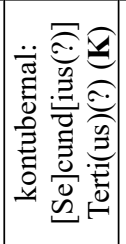 & 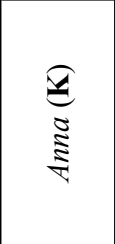 \\
\hline & & & & & 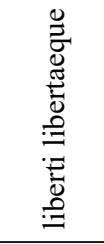 & & & & & \\
\hline & & 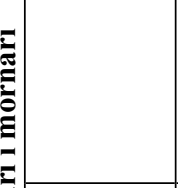 & & & & & 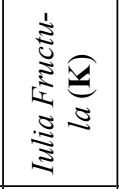 & & & \\
\hline 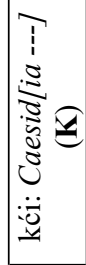 & 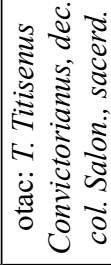 & & & & 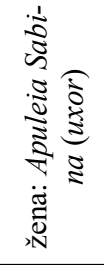 & 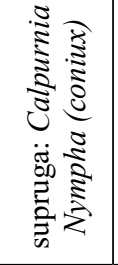 & & & & \\
\hline 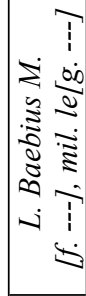 & 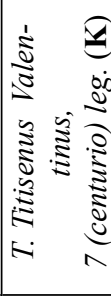 & 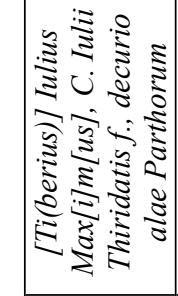 & 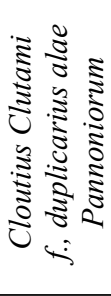 & 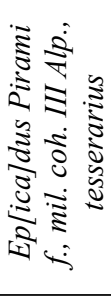 & 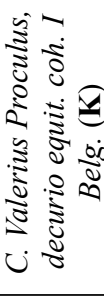 & 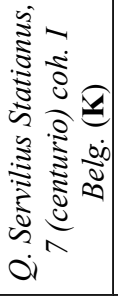 & 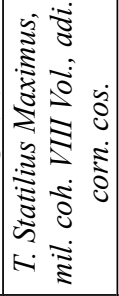 & 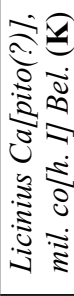 & 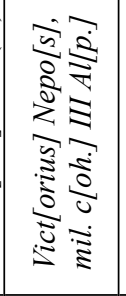 & 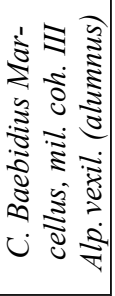 \\
\hline 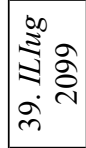 & 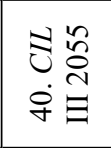 & 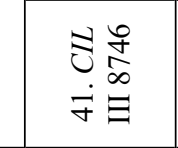 & 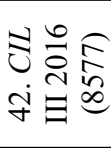 & 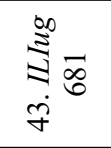 & $\begin{array}{l}: \mathbb{S} \\
0 \stackrel{\infty}{\infty} \\
\dot{7} \Xi\end{array}$ & 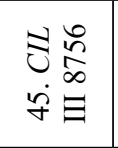 & 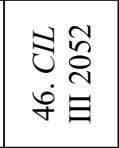 & 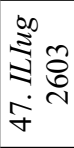 & 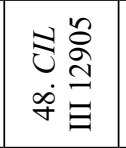 & 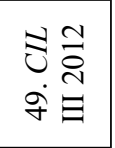 \\
\hline
\end{tabular}




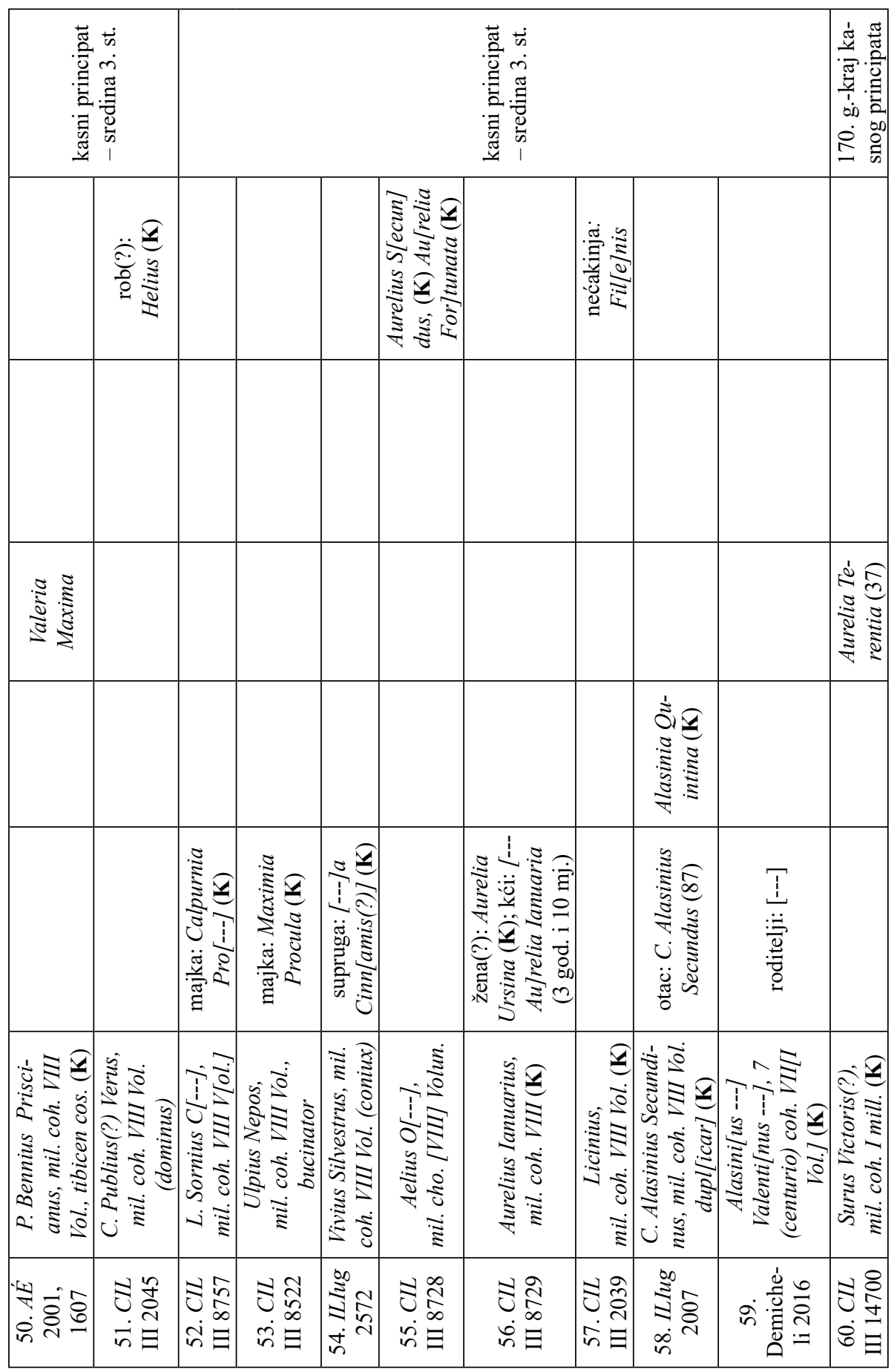




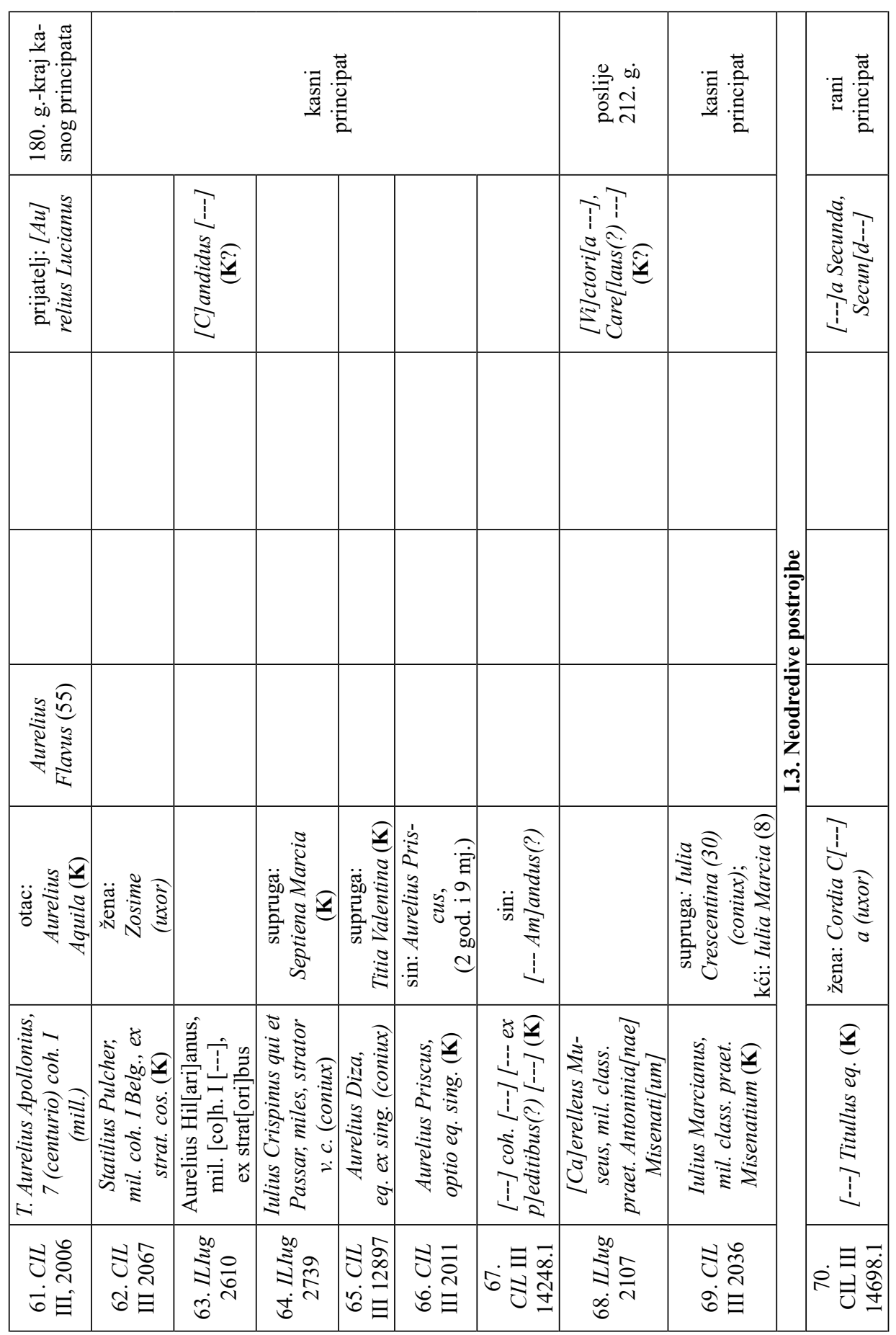




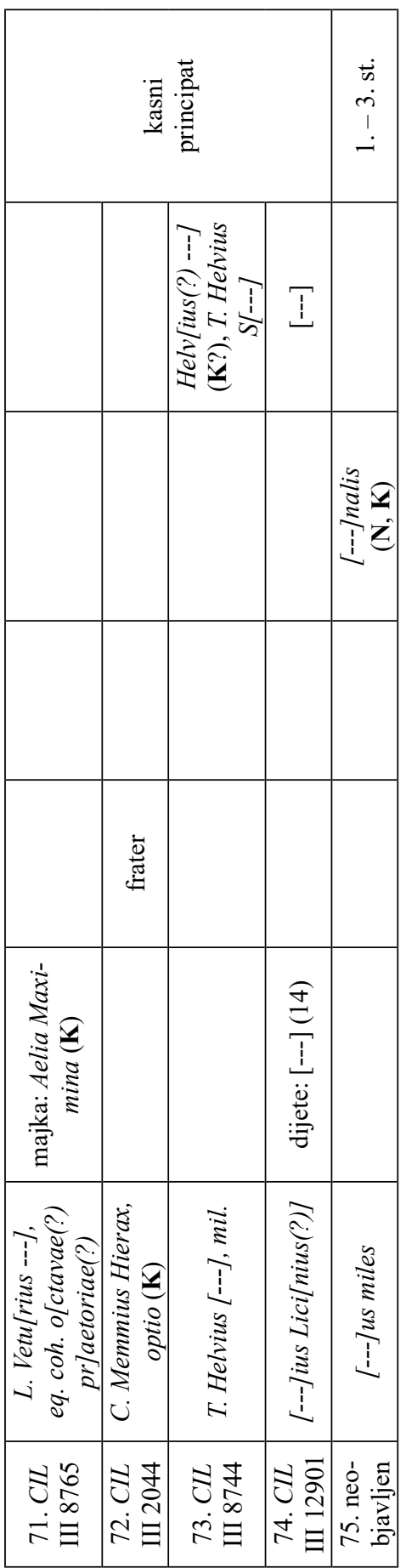




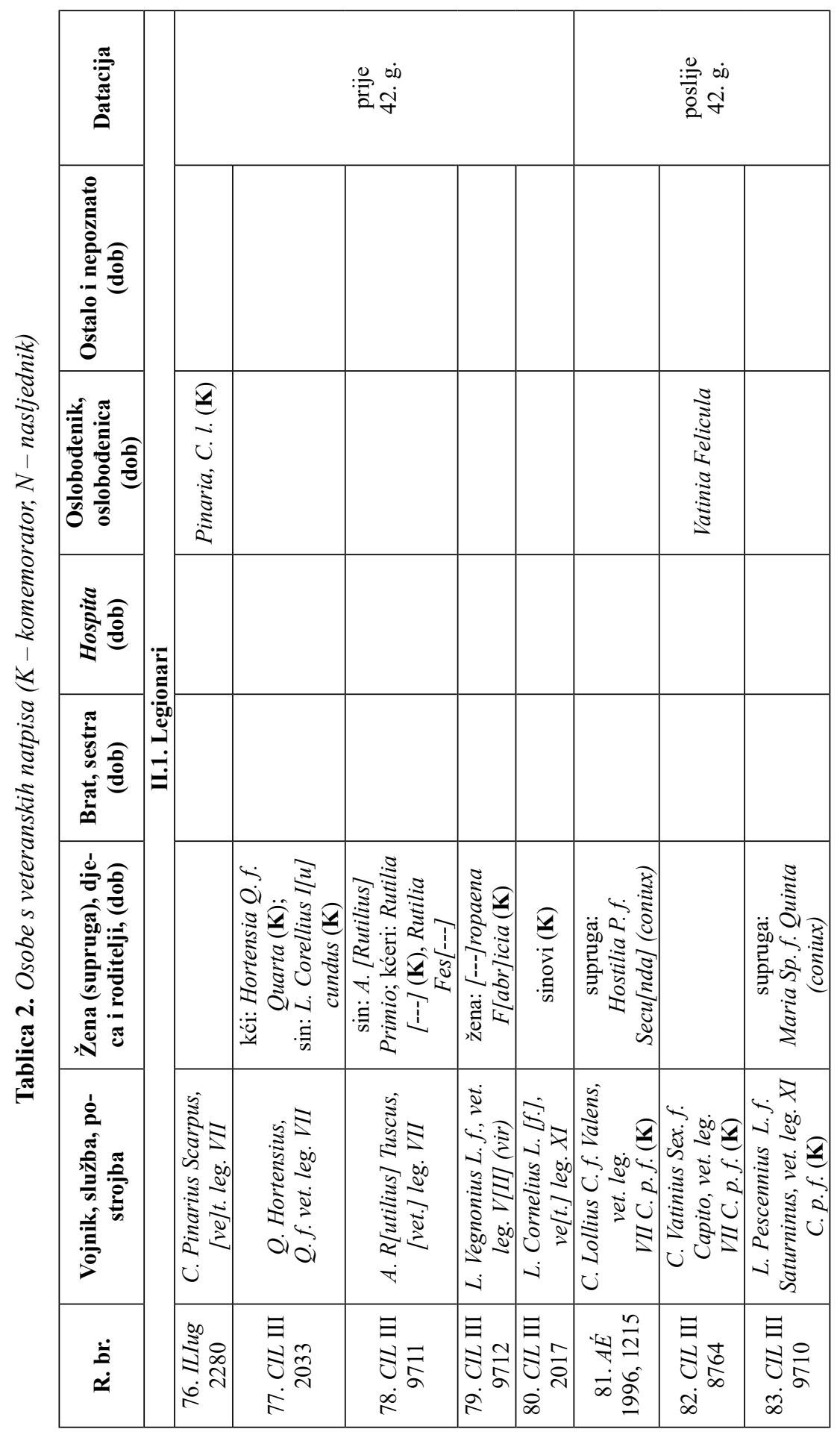


Ivan Matijević - Životni suputnici rimskih vojnika na salonitanskim nadgrobnim natpisima...

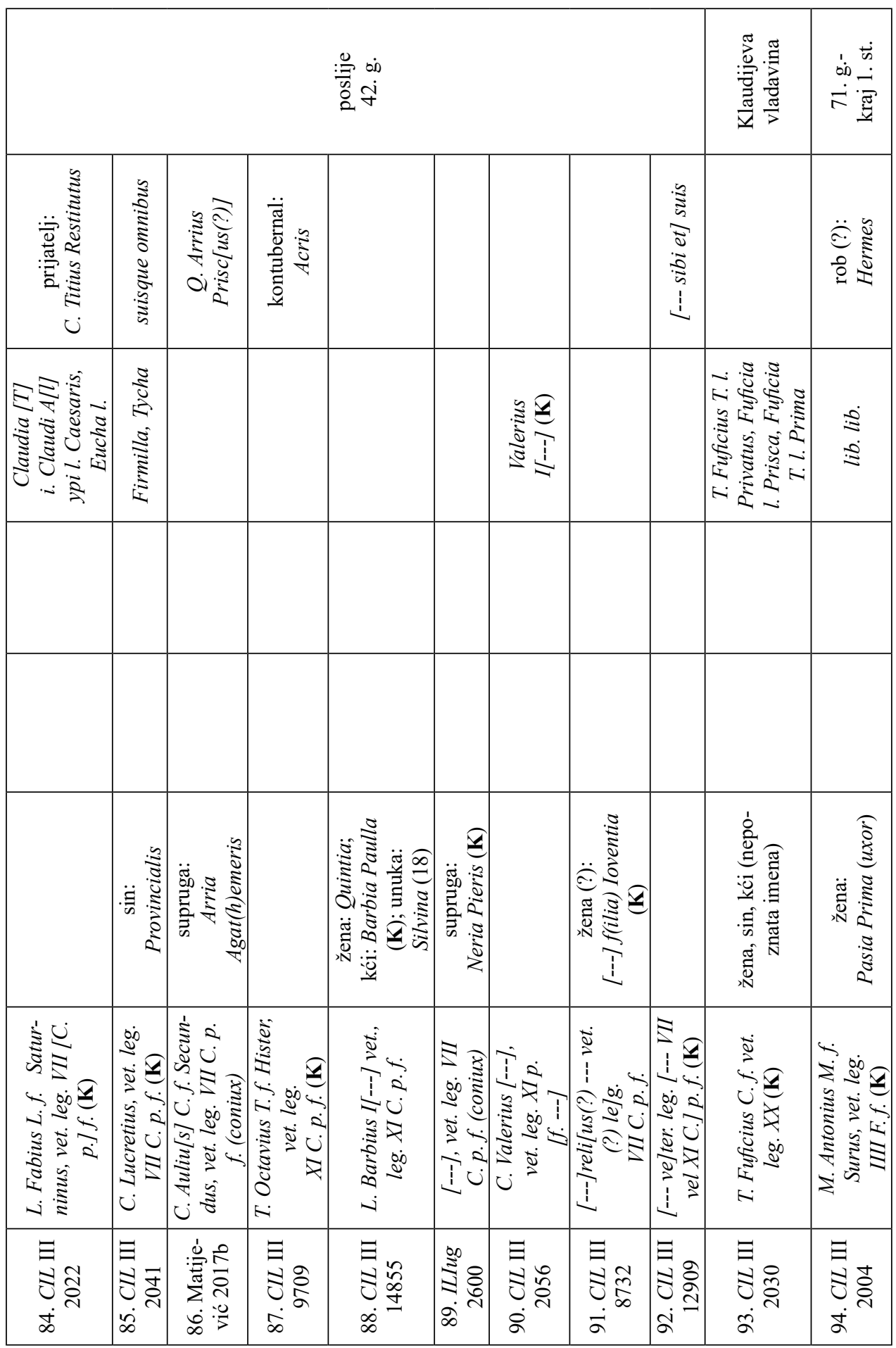




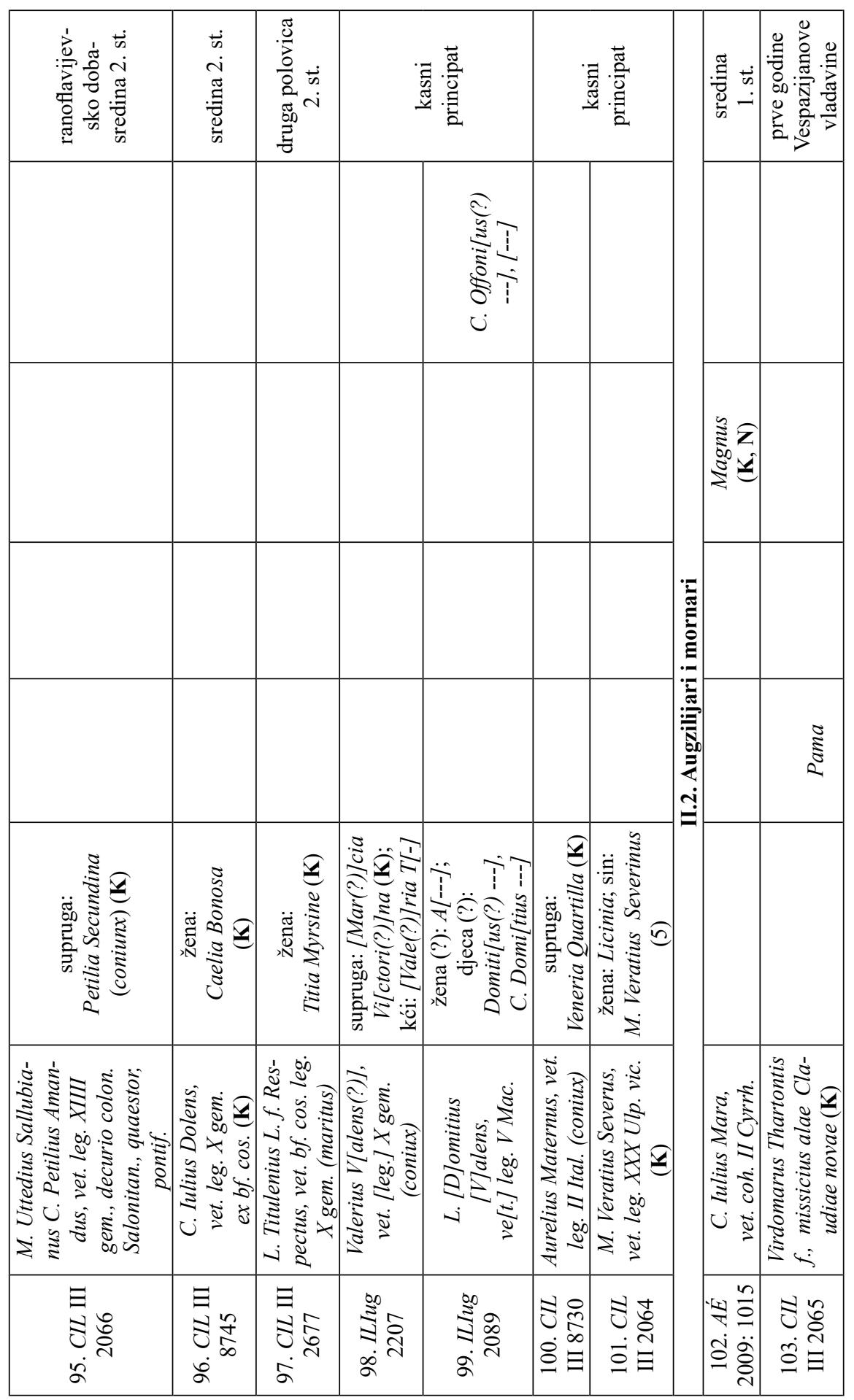


Ivan Matijević - Životni suputnici rimskih vojnika na salonitanskim nadgrobnim natpisima...

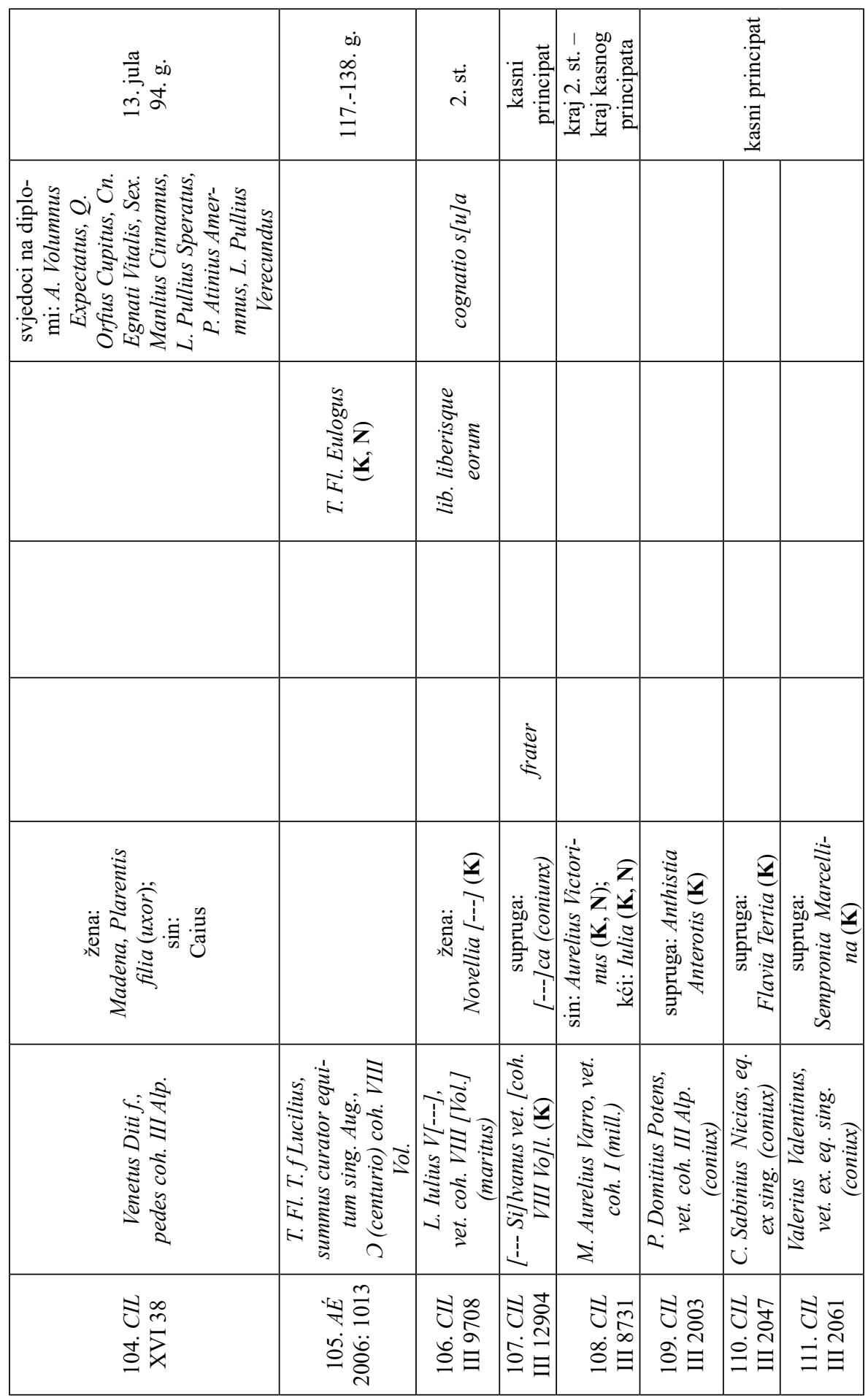




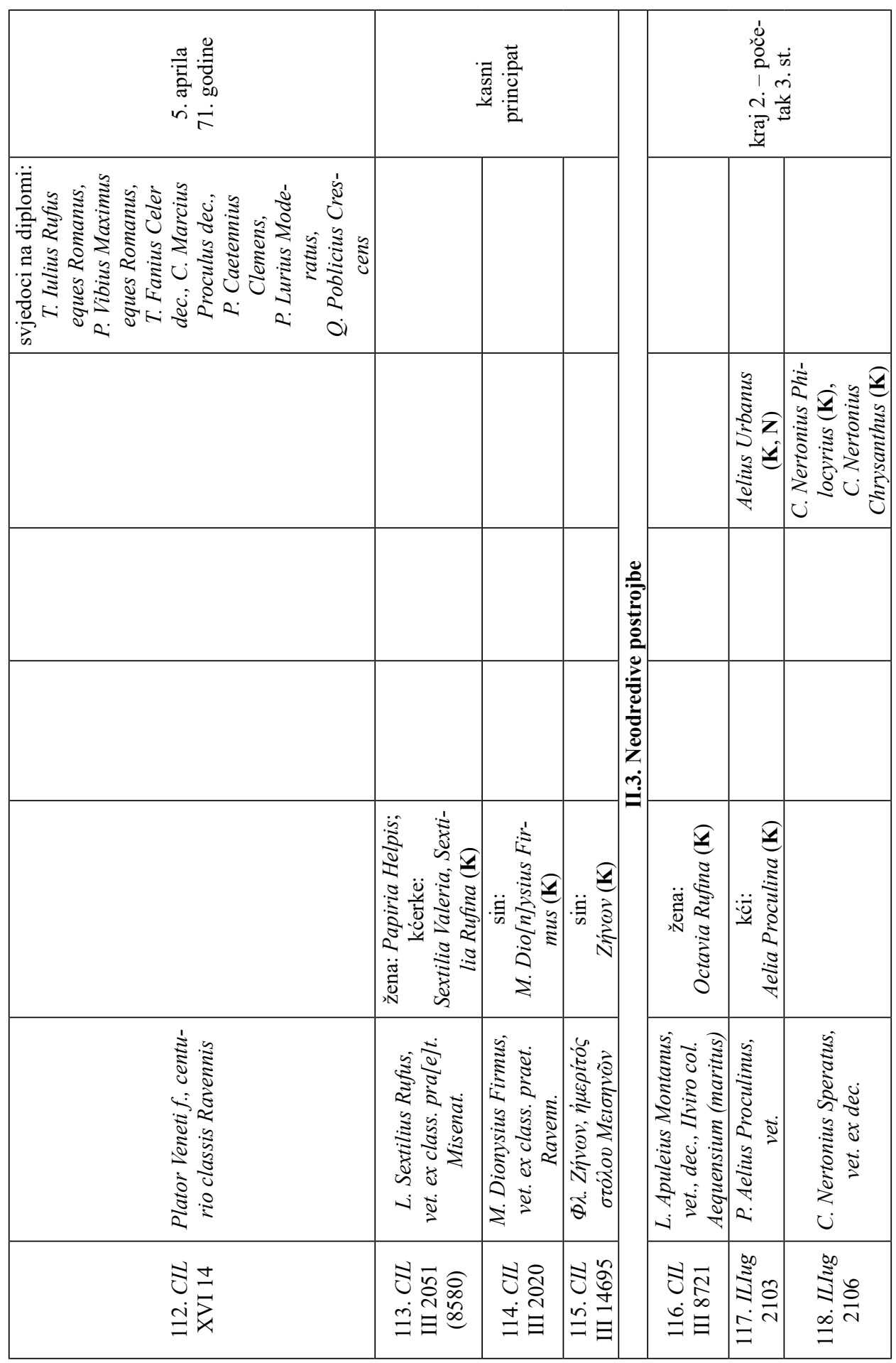




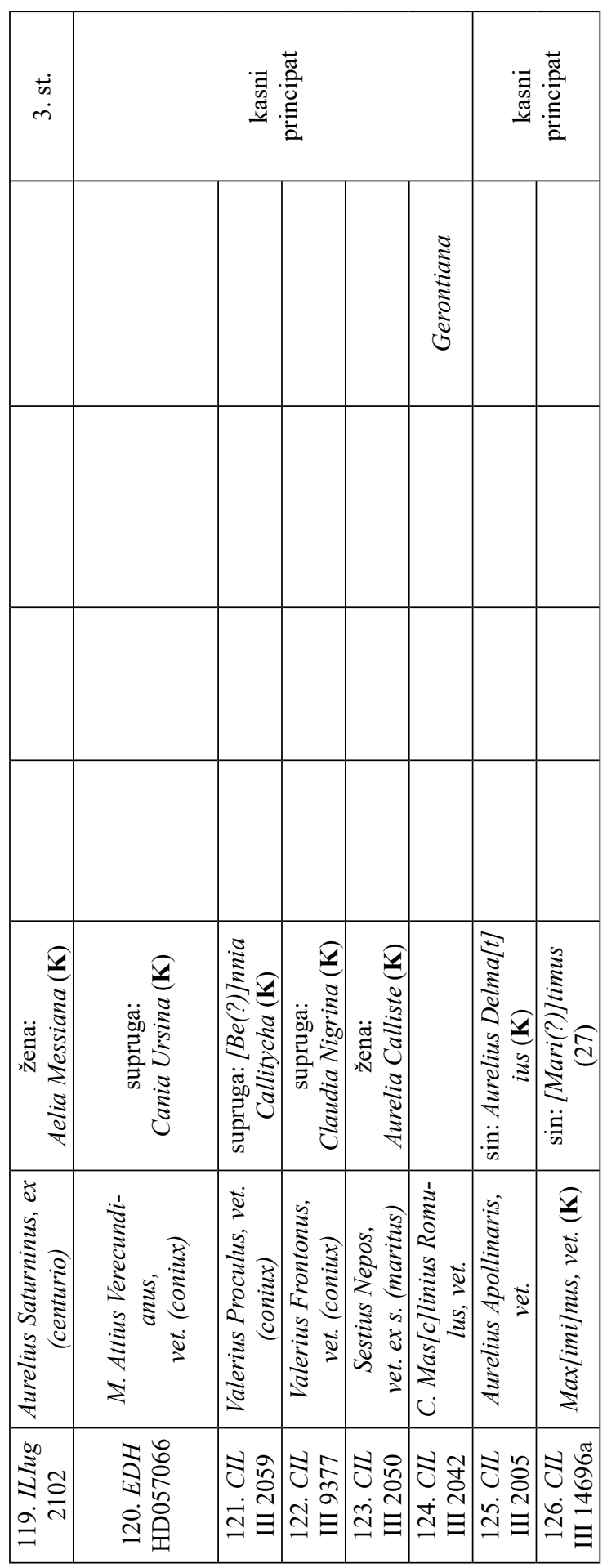




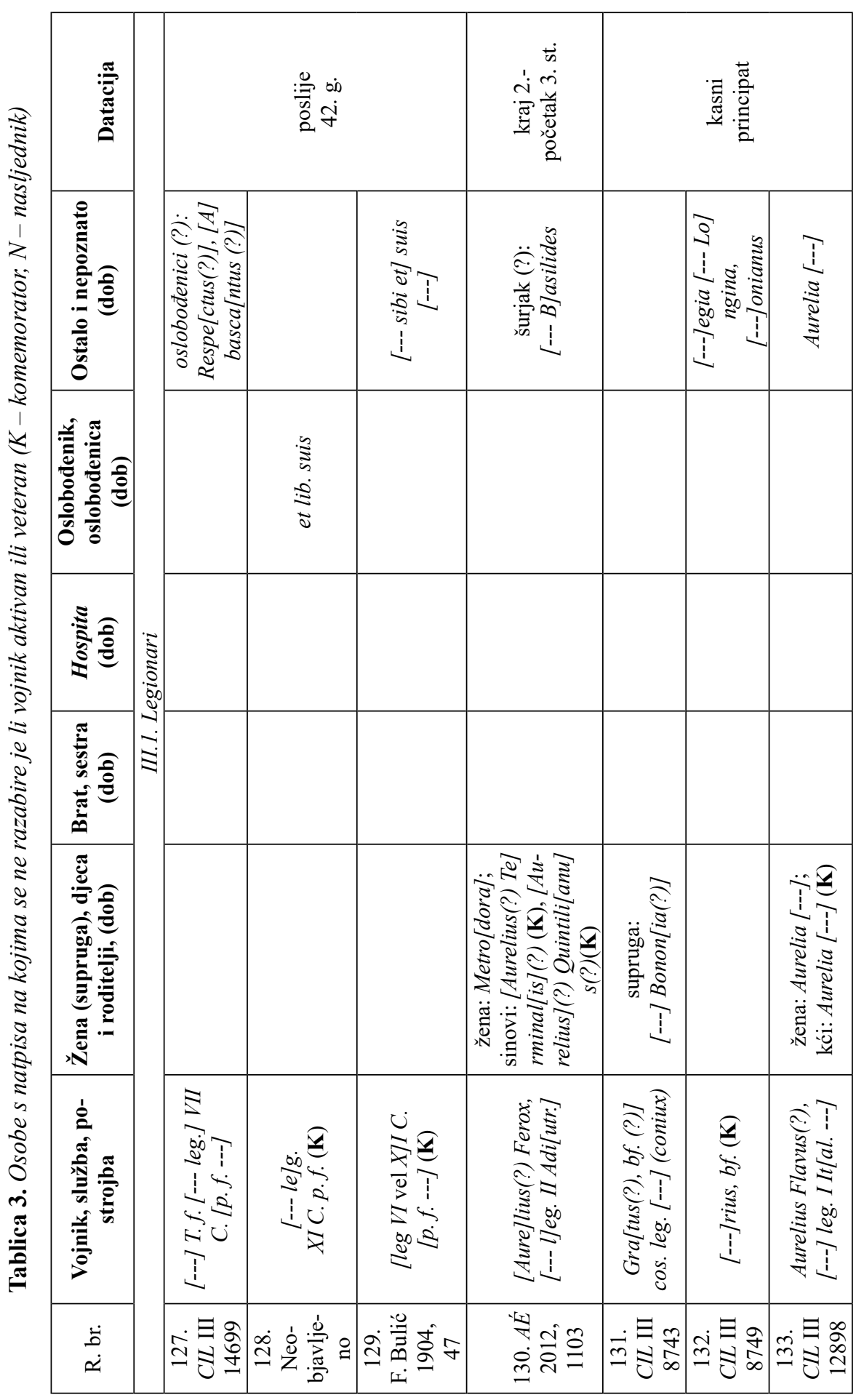




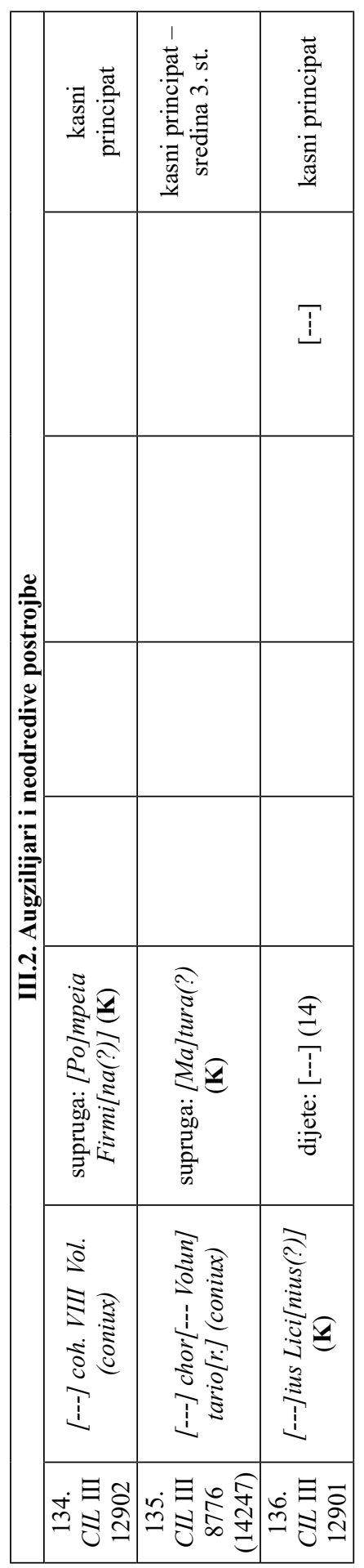




\section{Life companions of Roman soldiers mentioned on the funerary inscriptions from Salona during the time of the Principate}

The paper analyzes 136 soldiers' inscriptions from Salona from the time of the principate, which, in addition to the name of a soldier or veteran, contain the name of one or more persons. At least 190 persons related to soldiers and veterans were mentioned in various contexts. Most often, it is their wives (coniunx, uxor) with whom they had children, then the freedmen and freedwoman named or by the usual syntagm (lib. libertabusque), parents, blood brothers, sisters, brothers in arms, friends, slaves, hospitae... Some of them are also listed as heirs of deceased soldiers and veterans. Only few inscriptions don't indicate the character of the relationship between a soldier and a person, but it can still be assumed. An attempt was made to determine who commemorated whom, and the analysis of the names should make it possible to determine the origin of these persons and their social status.

Key words: Salona, tombstones, Roman army, soldier, veteran, contubernalis, family, familia, relatives, freedman

Ključne riječi: Salona, nadgrobni spomenici, postrojbe rimske vojske, vojnik, veteran, contubernalis, obitelj, familia, srodnici u 1. i 2. koljenu, oslobođenici

Ivan Matijević Filozofski fakultet Sveučilišta u Splitu, Poljička 35 21000 Split imatijev@ffst.hr 


\section{FILOZOFSKI FAKULTET SVEUČILIŠTA U ZAGREBU \\ ZAVOD ZA HRVATSKU POVIJEST \\ INSTITUTE OF CROATIAN HISTORY \\ INSTITUT FÜR KROATISCHE GESCHICHTE}

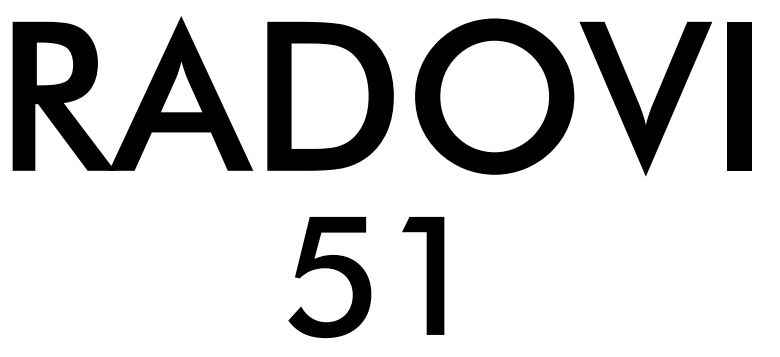

BROJ 2

ZAVOD ZA HRVATSKU POVIJEST

FILOZOFSKOGA FAKULTETA SVEUČILIŠTA U ZAGREBU

\section{FF press}

ZAGREB 2019. 


\title{
RADOVI ZAVODA ZA HRVATSKU POVIJEST FILOZOFSKOGA FAKULTETA SVEUČILIŠTA U ZAGREBU
}

\author{
Knjiga 51, broj 2
}

\author{
Izdavač / Publisher \\ Zavod za hrvatsku povijest \\ Filozofskoga fakulteta Sveučilišta u Zagrebu \\ FF-press \\ Za izdavača / For Publisher \\ Vesna Vlahović Štetić \\ Glavni urednik / Editor-in-Chief \\ Inga Vilogorac Brčić \\ Izvršni urednik / Executive Editor \\ Kornelija Jurin Starčević \\ Uredništvo / Editorial Board
}

Jasmina Osterman (stara povijest/ancient history), Trpimir Vedriš (srednji vijek/medieval history), Hrvoje Petrić (rani novi vijek/early modern history), Željko Holjevac (moderna povijest/ modern history), Tvrtko Jakovina (suvremena povijest/contemporary history), Silvija Pisk

(mikrohistorija i zavičajna povijest/microhistory and local history),

Zrinka Blažević (teorija i metodologija povijesti/theory and methodology of history)

Međunarodno uredničko vijeće / International Editorial Council

Denis Alimov (Sankt Peterburg), Živko Andrijašević (Nikšić), Csaba Békés (Budapest), Rajko

Bratož (Ljubljana), Svetlozar Eldarov (Sofija), Toni Filiposki (Skopje), Aleksandar Fotić

(Beograd), Vladan Gavrilović (Novi Sad), Alojz Ivanišević (Wien),

Egidio Ivetić (Padova), Husnija Kamberović (Sarajevo), Karl Kaser (Graz),

Irina Ognyanova (Sofija), Géza Pálffy (Budapest), Ioan-Aurel Pop (Cluj),

Nade Proeva (Skopje), Alexios Savvides (Kalamata), Vlada Stanković (Beograd),

Ludwig Steindorff (Kiel), Peter Štih (Ljubljana)

Izvršni urednik za tuzemnu i inozemnu razmjenu /

Executive Editor for Publications Exchange

Martin Previšić

Tajnik uredništva / Editorial Board Assistant

Dejan Zadro

Adresa uredništva/Editorial Board address

Zavod za hrvatsku povijest, Filozofski fakultet Zagreb, Ivana Lučića 3, HR-10 000, Zagreb Tel. ++385(0)1 6120191

Časopis izlazi jedanput godišnje / The Journal is published once a year

Časopis je u digitalnom obliku dostupan na / The Journal in digital form is accessible at Portal znanstvenih časopisa Republike Hrvatske „Hrčak“ http://hrcak.srce.hr/radovi-zhp

Financijska potpora za tisak časopisa / The Journal is published with the support by Ministarstvo znanosti, obrazovanja i športa Republike Hrvatske

Časopis je indeksiran u sljedećim bazama / The Journal is indexed in the following databases: Directory of Open Access Journals, EBSCO, SCOPUS, ERIH PLUS, Emerging Sources Citation Index - Web of Science 


\title{
Naslovna stranica / Title page by Marko Maraković
}

\section{Grafičko oblikovanje i računalni slog / Graphic design and layout Marko Maraković}

\author{
Lektura / Language editors \\ Samanta Paronić (hrvatski / Croatian) \\ Edward Bosnar (engleski / English)
}

Tisak / Printed by

Tiskara Zelina, Sv. Ivan Zelina

Naklada / Issued

200 primjeraka / 200 copies

Ilustracija na naslovnici

Muza Klio (Alexander S. Murray, Manual of Mythology, London 1898)

Časopis je u digitalnom obliku dostupan na Portalu znanstvenih časopisa Republike Hrvatske ,Hrčak“ http://hrcak.srce.hr/radovi-zhp

The Journal is accessible in digital form at the Hrcak - Portal of scientific journals of Croatia http://hrcak.srce.hr/radovi-zhp 